
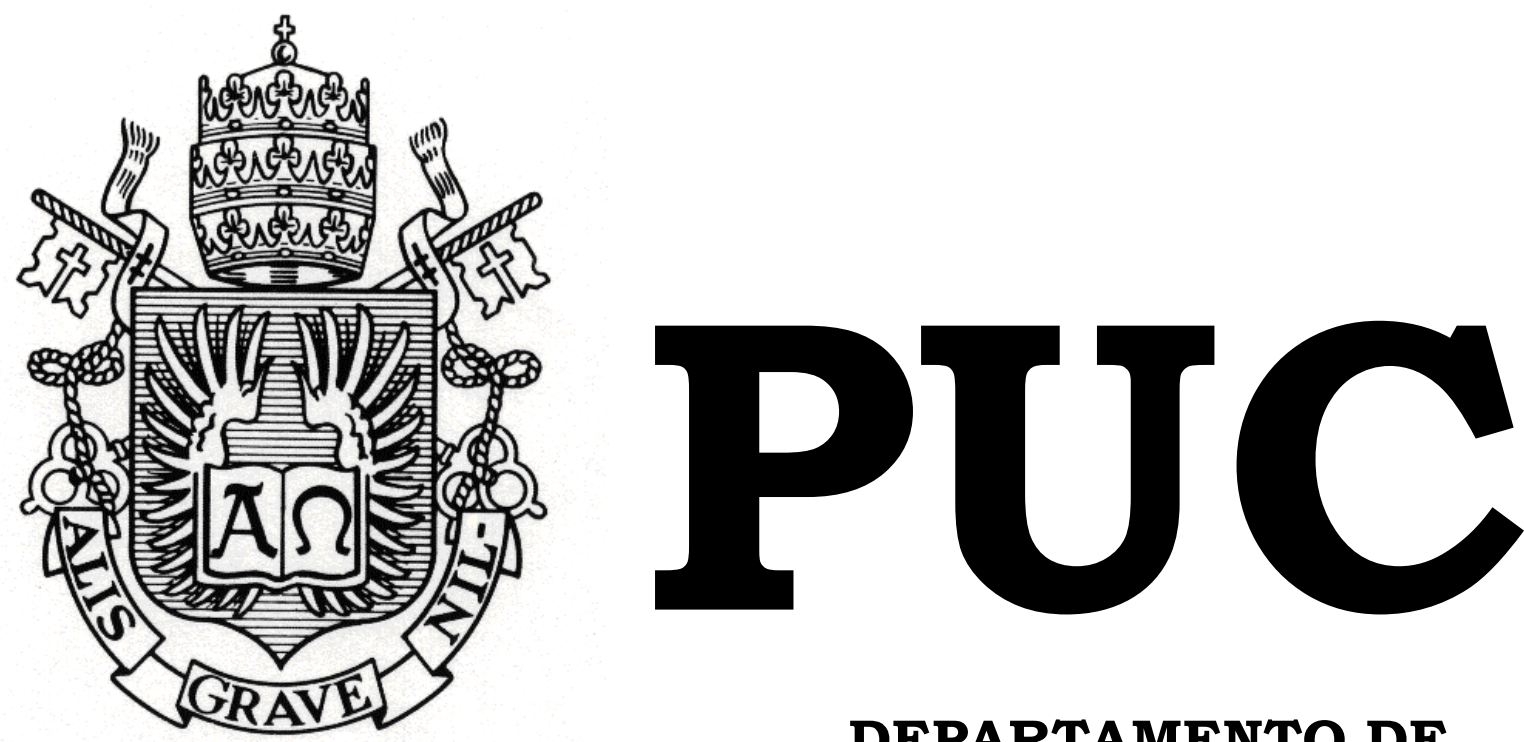

DEPARTAMENTO DE DIREITO

\begin{abstract}
A EXCLUSÃO DE RESPONSABILIDADE CIVIL CONTRATUAL NO CÓDIGO CIVIL BRASILEIRO E NA CONVENÇÃO DE VIENA SOBRE COMPRA E VENDA INTERNACIONAL DE MERCADORIAS
\end{abstract}

$$
\text { por }
$$

\title{
GIULIA JORDAN
}

ORIENTADOR: LAURO GAMA JR.

2012.2

PONTIFÍCIA UNIVERSIDADE CATÓLICA DO RIO DE JANEIRO - RUA MARQUÊS DE SÃO VICENTE, 225 - CEP

$$
\text { 22453-900 }
$$

RIO DE JANEIRO - BRASIL 


\section{A EXCLUSÃO DE RESPONSABILIDADE CIVIL CONTRATUAL NO CÓDIGO CIVIL BRASILEIRO E NA CONVENÇÃO DE VIENA SOBRE COMPRA E VENDA INTERNACIONAL DE MERCADORIAS}

por

\section{GIULIA JORDAN}

Monografia apresentada ao Departamento de Direito da Pontifícia Universidade Católica do Rio de Janeiro (PUC-Rio) para a obtenção do Título de Bacharel em Direito.

Orientador: Lauro Gama Jr. 


\section{AGRADECIMENTOS}

Ao meu orientador, Professor Lauro Gama Jr., por todas as lições acadêmicas e pela paciência e boa vontade na elaboração deste trabalho e na coordenação do Grupo de Estudos em Arbitragem e Direito do Comércio Internacional da PUC-Rio (GEADICI). A ele meus sinceros agradecimentos.

À todos os membros do GEADICI que me apresentaram, pela primeira vez, o desafio da busca pela excelência.

À todos os integrantes da Aventura Entretenimento, por todo carinho, aprendizado e criatividade que, sem dúvida, tornam a vida mais colorida.

À minha família, amigos e amores. Sem eles, a vida não valeria a pena. 


\section{RESUMO}

O presente trabalho tem por objetivo analisar as regras referentes à exclusão de responsabilidade civil contratual quando há a ocorrência de evento fortuito ou de força maior, na legislação brasileira e na Convenção de Viena sobre Compra e Venda Internacional de Mercadorias (CISG). Para tanto, foi feito estudo sobre o Artigo 79 da CISG e sobre o Artigo 393 do Código Civil Brasileiro. Em tentativa de tornar a análise mais clara ao leitor, um caso concreto foi apresentado e analisado à luz de ambas as legislações.

O tema do presente trabalho monográfico foi escolhido vez que o Brasil encontra-se a caminho de ratificar a CISG, e seus dispositivos diferem bastante da legislação nacional, principalmente no tocante à exclusão de responsabilidade civil contratual. 


\section{PALAVRAS-CHAVE}

CONVENÇÃO DE VIENA SOBRE COMPRA E VENDA INTERNACIONAL DE MERCADORIAS. CÓDIGO CIVIL BRASILEIRO. EXEMPTION. CASO FORTUITO E FORÇA MAIOR. EXCLUSÃO DE RESPONSABILIDADE CIVIL CONTRATUAL. 


\section{SUMÁRIO}

INTRODUÇÃO

1

1. Cláusula de Exoneração da Responsabilidade Civil

CONTRATUAL (EXEMPTION) NA CISG ........................................

$\begin{array}{llll}\text { 1.1.REQUiSITOS } & \text { DO } & \text { ARTIGO }\end{array}$

. .8

1.1.1.IMPEDIMENTO ALÉM DO CONTROLE DA PARTE INADIMPLENTE.

1.1.2.IMPEDIMENTO IMPREVISÍVEL NO MOMENTO DA FORMAÇÃO DO CONTRATO.

1.1.3.IMPEDIMENTO IMPOSSÍVEL DE SE EVITAR OU COM CONSEQUÊNCIAS IMPOSSIIVEIS DE SEREM EVITADAS OU SUPERADAS.

1.1.4.IMPEDIMENTO COMO A CAUSA EXCLUSIVA DO INADIMPLEMENTO .24

1.2.A APLICAÇÃO $\quad$ DO ARTIGO $79 \quad$ (2). .25

1.3.IMPEDIMENTOS TEMPORÁRIOS - ARTIGO 79(3).

1.4.NOTIFICAÇÃO DE EXONERAÇÃO - ARTIGO 79(4).

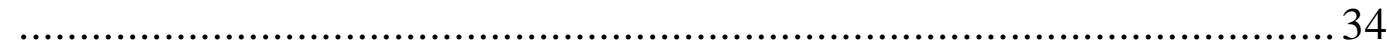

$\begin{array}{lllll}\text { 1.5.EFEITOS DA APLICAÇÃO } & \text { DO ARTIGO } & 79 .\end{array}$

1.6.ANÁLISE DO CASO HIPOTÉTICO APRESENTADO À LUZ DO ARTIGO 79

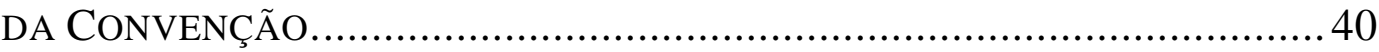

2. A Exclusão da Responsabilidade Civil Contratual em VirTude de Caso Fortuito ou de Força Maior no Código CiviL BRASILEIRO 43

2.1.CASO FORTUITO E FORÇA MAIOR: 
2.1.1.CONCEITO E DistinçÃo DE Agostinho Alvim

2.1.2.REQUISITOS

DOUTRINÁRIOS.

54

2.2.EFEITOS DA APLICAÇÃO DO CASO FORTUITO E FORÇA MAIOR. .58

2.3.ANÁlise o CASO HiPOTÉtico APRESENTADO À LUZ DO ARTIGO 393 Do CóDIGO Civil BRASILEIRO.....................................................6 61

CONCLUSÃO

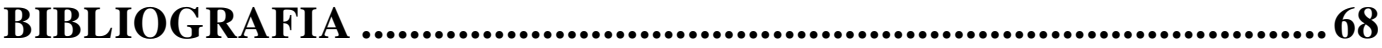




\section{INTRODUÇÃO}

Imagine uma empresa italiana que produz conferências ("Elite"). Elite compra um iate e visa instalar nele toda a tecnologia necessária para realizar as conferências de seus luxuosos clientes. Dentre inúmeros fornecedores, Elite contrata uma empresa brasileira ("HP”) para produzir, instalar e configurar um sistema de controle máster, essencial para a realização de conferências. O elemento central desse sistema de controle máster eram unidades de processamento de tecnologia de ponta, que seriam produzidas pela empresa Dell (“Dell”), contratada por HP.

De acordo com o cronograma que Elite informou à $\mathrm{HP}$, a reforma do iate deveria estar finalizada em meados novembro e, para que isso ocorresse, HP deveria entregar o sistema de controle máster no início do mesmo mês. Elite, então, contratou a estreia do iate, seu novíssimo local de conferências, para fevereiro, com seu melhor cliente. Haveria um longo período de testes de todos os equipamentos instalados, para que nada de errado acontecesse na tão esperada estreia.

Tudo corre bem até que Dell, subcontratada de HP, não entrega as unidades de processamento na data acordada em função de um incêndio em sua fábrica. O incêndio havia destruído grande parte do estoque de Dell. As unidades remanescentes seriam entregues a outra empresa, cliente antiga de Dell.

HP, então, informa Elite que não irá entregar o sistema de controle máster a tempo do primeiro evento no iate em função de um incêndio acidental na fábrica de seu fornecedor. Para não perder seu melhor cliente, Elite aluga um iate substituto por preço muito elevado, incorre em prejuízo e processa HP por quebra contratual. 
Com a publicação, em 19/10/2012, do Decreto Legislativo 538/2012, que aprova o texto da Convenção de Viena sobre Contratos de Compra e Venda Internacional de Mercadorias (doravante "CISG” ou "Convenção"), o Brasil encontra-se em processo de adesão da mesma, faltando apenas a promulgação do decreto presidencial para que faça parte de nossa legislação. Imagine então, que o caso apresentado ocorresse após a ratificação da Convenção pelo Brasil. Como seria solucionado? A solução do caso, através da CISG, diferiria da solução dada pelo Código Civil Brasileiro?

A Convenção é instrumento de direito uniforme e destina-se a reger unicamente os contratos de compra e venda internacional - sua formação e os direitos e obrigações que deles resultam. Atualmente, setenta e oito Estados, representativos de cerca de $80 \%$ do comércio mundial, aderiram à Convenção ${ }^{1}$. Com o crescimento da participação do Brasil no comércio internacional de mercadorias, inúmeros acontecimentos ao redor do mundo podem afetar o cumprimento dos contratos, ensejando o surgimento de litígios. Por isso, é importante entender como o direito uniforme da CISG funciona, em particular nos casos de exoneração das obrigações, em comparação ao Código Civil Brasileiro.

Para entender a CISG, temos que ter em mente a forma de interpretála. O legislador convencional estabeleceu critérios que devem ser observados ao se interpretar e aplicar a Convenção. De acordo com o artigo $7(1)^{2}$, são eles: (i) caráter internacional da Convenção; (ii) necessidade de se promover a uniformidade em sua aplicação; e (iii) princípio da boa fé no

\footnotetext{
${ }^{1}$ De acordo com o site da UNCITRAL:

http://www.uncitral.org/uncitral/en/uncitral_texts/sale_goods/1980CISG_status.html.

2 “Artigo 7: (1) Na interpretação desta Convenção ter-se-ão em conta seu caráter internacional e a necessidade de promover a uniformidade de sua aplicação, bem como de assegurar o respeito à boa fé no comércio internacional. (...)” Tradução de Eduardo Grebler e Gisely Radael, disponível em http://www.cisg-brasil.net/doc/egrebler2.pdf.
} 
comércio internacional. Em função de seu caráter internacional, a CISG é formulação jurídica independente de todos os direitos nacionais e das "famílias" de sistemas jurídicos ${ }^{3}$.

De acordo com o parágrafo segundo do mesmo Artigo 7, eventuais lacunas da CISG devem ser preenchidas de acordo com "os princípios gerais que a inspiram", e que fazem parte do direito do comércio internacional. Nesse sentido, afirma Mauricio Almeida Prado que " a busca de soluções nos direitos nacionais para auxiliar a interpretação da

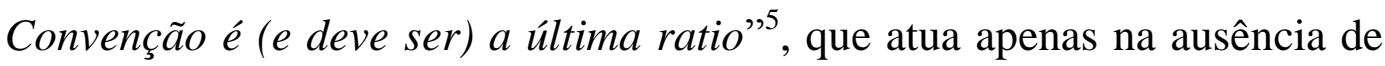
um princípio de direito internacional aplicável ao caso concreto.

A Convenção visa promover a adoção de regras uniformes para reger a troca internacional de mercadorias. Com isso, tem-se o objetivo de eliminar alguns dos obstáculos às trocas internacionais e promover o desenvolvimento do comércio internacional, uma vez que garante maior segurança jurídica às partes de uma compra e venda internacional ${ }^{6}$.

Um dos problemas mais graves de desvio de interpretação decorre da confusão que se faz entre os conceitos convencionais e aqueles típicos da

\footnotetext{
3 ALMEIDA PRADO, Maurício; "Interpretação e aplicação da regra de "Exoneração" da Convenção de Viena (1980)", p. 1. Esse estudo foi inicialmente publicado no livro "Arbitragem Internacional - UNCITRAL, CISG e Direito Brasileiro”, São Paulo, Quartier Latin, 2010.

4 “Artigo 7: (...) (2) As questões referentes às matérias reguladas por esta Convenção que não forem por ela expressamente resolvidas serão dirimidas segundo os princípios gerais que a inspiram ou, à falta destes, de acordo com a lei aplicável segundo as regras de direito internacional privado." Tradução de Eduardo Grebler e Gisely Radael, disponível em http://www.cisg-brasil.net/doc/egrebler2.pdf.

5 ALMEIDA PRADO, Maurício; “Interpretação e aplicação da regra de "Exoneração" da Convenção de Viena (1980)", p. 2. Esse estudo foi inicialmente publicado no livro "Arbitragem Internacional - UNCITRAL, CISG e Direito Brasileiro”, São Paulo, Quartier Latin, 2010.

${ }^{6}$ SPIVACK, Carla; "Of Shrinking Sweatsuits and Poison Vine Wax: A Comparison of Excuse for Nonperformance under the UCC and the CISG"; Oklahoma City University, disponível em http://law.bepress.com/expresso/eps/1219.
} 
lei do foro $^{7}$. Nesse sentido, essa monografia procura diferenciar os conceitos de exoneração de responsabilidade civil na CISG e, de outro lado, de caso fortuito e força maior no Código Civil Brasileiro. O Artigo 79 da Convenção estabelece requisitos para a exoneração de responsabilidade civil da parte que descumpriu a obrigação contratual, sem, no entanto, usar o conceito derivado do direito romano-germânico de força maior. Tal foi feito para que não houvesse uma pré-disposição do intérprete de recorrer ao direito nacional para interpretar a regra - o Artigo 79 deve ser interpretado de forma autônoma.

Ao longo desse trabalho, analisaremos os conceitos de exoneração de responsabilidade do Artigo 79 da CISG e de caso fortuito e força maior do Artigo 393 do Código Civil Brasileiro. Através dessa análise, veremos a provável solução do caso hipotético apresentado à luz de ambas as legislações.

\footnotetext{
${ }^{7}$ TRIPODI, Leandro, "Interpretação da CISG: contexto, lex forismo, uniformidade e o intuito do legislador convencional".
} 


\section{CAPÍTULO PRIMEIRO}

\section{Cláusula de Exoneração da Responsabilidade Civil Contratual (exemption) na CISG}

O conceito de exoneração das obrigações contratuais ("exemption"), assim como qualquer outro artigo da CISG, deve ser interpretado sob o prisma da internacionalidade, da neutralidade e da autonomia em relação a institutos similares de direito interno ${ }^{8}$. O Artigo 79 regula a exoneração do devedor da responsabilidade de pagar perdas e danos se ele não for capaz de cumprir sua obrigação de acordo com o contrato, em função de um "impedimento" imprevisível e fora de seu controle ${ }^{9}$. O termo utilizado pela CISG, "exoneração" (ou exemption), se refere a uma obrigação universal de cumprir com os termos do contrato, que só pode ser suspensa em raros $\operatorname{casos}^{10}$.

Segundo Schwenzer, o Artigo 79 constitui a limitação necessária ao principio de responsabilidade estrita pelo inadimplemento do contrato, que está presente nos demais artigos da Convenção. Em contratos regulados pela CISG, é muito difícil de se configurar a exclusão de responsabilidade da parte inadimplente ${ }^{11}$.

\footnotetext{
${ }^{8}$ Nesse sentido, afirma John Honnold que:"The Convention (Art. 7) enjoins us to interpret its provisions "with regard for its international character and...the need to promote uniformity in its application." This goal would be served if we could (as by a draft from Lethe) purge our minds of presuppositions derived from domestic traditions and, with innocent eyes, read the language of Article 79 in the light of the practices and needs of international trade" [HONNOLD, John, "Uniform Law for International Sales Under the 1980 United Nations Convention"; $3^{\mathrm{a}}$ edição (1999), disponível em http://www.cisg.law.pace.edu/cisg/biblio/honnold.html].

${ }^{9}$ SCHELECHTRIEM, Peter e SCHWENZER, Ingeborg, "Commentary on the UN Convention on the International Sale of Goods (CISG)”, 3ª edição, Oxford University Press, 2010, p. 1063.

${ }^{10}$ SPIVACK, Carla; "Of Shrinking Sweatsuits and Poison Vine Wax: A Comparison of Excuse for Nonperformance under the UCC and the CISG"; Oklahoma City University, p. 13, disponível em http://law.bepress.com/expresso/eps/1219.

${ }^{11}$ Nesse sentido, a opinião n ${ }^{\circ} 7$ do Advisory Council da CISG: “(...) Article 79 has been invoked in litigation and arbitration by sellers and buyers with limited success" [CISG-AC Opinion No. 7, "Exemption of Liability for Damages under Article 79 of the CISG", Rapporteur: Professor Alejandro M. Garro, Columbia University School of Law, New York, N.Y., USA. Adotado pela
} 
A circunstância necessária para que o devedor alcance a exoneração da responsabilidade através da aplicação do Artigo 79 da CISG é muito diferente das situações encontradas em leis nacionais, tais como no Código Civil Alemão, Italiano ou Francês, ou em projetos de leis contratuais uniformes, tais como o PECL (Principles of European Contract Law) ${ }^{12} \mathrm{e} \mathrm{o}$ PICC (UNIDROIT Principles of International Commercial Contracts) ${ }^{13}$. De acordo com Schwenzer, a maioria das regras nacionais sobre exoneração levam em consideração o principio da culpa: a exoneração da responsabilidade será concedida caso a culpa pelo inadimplemento não possa ser atribuída à parte inadimplente ${ }^{14}$. Na CISG, o foco não reside na

CISG-AC na $11^{\mathrm{a}}$ reunião, em Wuhan, República Popular da China, em 12 de Outubro de 2007, disponível em http://www.cisg.law.pace.edu/cisg/CISG-AC-op7.html].

SCHELECHTRIEM, Peter e SCHWENZER, Ingeborg, "Commentary on the UN Convention on the International Sale of Goods (CISG)”, 3 edição, Oxford University Press, 2010, p. 1063.

${ }^{12} \mathrm{O} P E C L$ é lei modelo europeia elaborada por especialistas europeus em contratos. A lei modelo pretende estabelecer regras básicas de obrigações e contratos presentes na maioria das legislações dos membros da União Europeia. Os Princípios se adéquam à ideia de criar um sistema contratual europeu uniforme.

${ }^{13}$ Os Princípios do UNIDROIT foram elaborados por organização criada em 1926, a International Institute for the Unification of Private Law (UNIDROIT). Os Princípios sobre Contratos do Comércio Internacional foram publicados, pela primeira vez, em 1994. Hoje já existem três edições, tendo a segunda sido lançada em 2004 e a terceira, em 2010. Tais Princípios representam uma sistematização de regras e princípios aplicáveis aos contratos internacionais em geral. São instrumento de soft law, que espelham o costume internacional em contratos comerciais. Em sua maioria, os Princípios do UNIDROIT refletem conceitos existentes em diversas legislações. No entanto, os Princípios tem o objetivo de estabelecer as melhores regras e soluções para transações comerciais internacionais. Por isso, por vezes adotam regras e princípios que não se adéquam à maioria dos sistemas jurídicos. O objetivo dos Princípios do UNIDROIT é estabelecer regras criadas para serem aplicadas ao redor do mundo, independentemente de tradições legais e condições econômicas ou políticas dos países nos quais serão aplicadas. Os Princípios não fazem referencia expressa a nenhuma legislação nacional. Há referência expressa apenas às regras da CISG, uma vez que os dois documentos tratam de questões semelhantes. Por essa razão, hoje defende-se a aplicação dos Princípios do UNIDROIT para preencher as lacunas e modernizar as regras da Convenção. Sobre isso, afirma Lauro Gama Jr. que: “(...) o diálogo entre a Convenção de Viena e normas de soft law, como os Princípios do UNIDROIT relativos aos Contratos do Comércio Internacional, constitui caminho viável - e necessário - de modernização do regime jurídico da compra e venda internacional de mercadorias, eis que, em realidade, são remotíssimas as chances de alteração da CISG mediante novo consenso diplomático entre os seus atuais 74 Estados-partes" [GAMA JR., Lauro, "Hardship nos contratos internacionais: o papel revigorante dos Princípios do UNIDROIT na evolução da Convenção de Viena", Publicado na Revista Trimestral de Direito Civil, ano 11, jul/set 2010, p. 205/229].

${ }^{14}$ SCHELECHTRIEM, Peter e SCHWENZER, Ingeborg, "Commentary on the UN Convention on the International Sale of Goods (CISG)”, $3^{\mathrm{a}}$ edição, Oxford University Press, 2010, p.1064. 
análise da culpa. A responsabilidade do devedor é objetiva e é conectada somente com o inadimplemento contratual - faz-se a análise do inadimplemento em si, e das circunstâncias que o cercam ${ }^{15}$. A Opinião número 7, expedida pelo Advisory Council da $\mathrm{CISG}^{16}$, ao comentar o julgamento do Caso Vine Wax, afirmou que “(...) the seller's liability under the CISG is one of guarantee, irrespective of fault (...)"17.

A exoneração da responsabilidade é passível de ser aplicada em qualquer caso onde uma das partes de um contrato não tenha cumprido com suas obrigações de forma correta. O tipo do inadimplemento - falha no cumprimento da obrigação em função de impedimento total ou de atraso, e a falha em função da entrega de bens defeituosos, em desconformidade com o contrato - é irrelevante ${ }^{18}$. Nesse sentido, a Corte Federal Suprema da

\footnotetext{
${ }^{15}$ Nesse sentido, o Tribunal de Primeira Instância de Atenas (Multi-Member Court of First Instance of Athens - Polimeles Protodikio Athinon), ao julgar o caso $n^{\circ}$ 4505-2009 (Bullet-proof vest case), em 2009, afirmou que:

“ (...) in order for liability to arise, it is not important if fault exists or not, i.e., the liability of the obligor is "objective" and it is connected only to the (objective) fact of the contractual breach. Therefore, pursuant to the CISG, the reason for the generation of liability is the breach of the contractual obligation itself and not the fault of the breaching party. (...)" [disponivel em: http://cisgw3.law.pace.edu/cases/094505gr.html].
}

${ }^{16}$ O Advisory Council da CISG é uma iniciativa privada, formada por profissionais de diferentes países, que tem o objetivo de promover uma interpretação e aplicação uniforme da Convenção. É uma iniciativa privada pois seus membros não representam nenhum país ou cultura jurídica em particular. Para mais informações, visite www.cisgac.com.

${ }^{17}$ CISG-AC Opinion No. 7, "Exemption of Liability for Damages under Article 79 of the CISG", Rapporteur: Professor Alejandro M. Garro, Columbia University School of Law, New York, N.Y., USA. Adotado pela CISG-AC na $11^{a}$ reunião, em Wuhan, República Popular da China, em 12 de Outubro de 2007, disponível em http://www.cisg.law.pace.edu/cisg/CISG-AC-op7.html.

${ }^{18}$ SCHELECHTRIEM, Peter e SCHWENZER, Ingeborg, "Commentary on the UN Convention on the International Sale of Goods (CISG)", $3^{\mathrm{a}}$ edição, Oxford University Press, 2010, p. 1065.

Nesse sentido, Schlechtriem, ao comentar o Caso Vine Wax: "The prevailing view, not only in Germany, is that "a failure to perform any obligation" within the meaning of Art. 79(1) CISG includes the delivery of non-conforming goods." [Federal Supreme Court (Bundesgerichtshof), Civil Panel VII March 24, 1999, Index No. VIII ZR 121/98, Comentário por Peter Schlechtriem, Tradução por Todd Fox e Sonja Corterier, disponível em http://cisgw3.law.pace.edu/cases/990324g1.html].

Nesse sentido também a Opinião número 7 do Advisory Council da CISG: "Cases in which a seller may be exempted of liability for delivering non-conforming goods are extremely rare. For example, goods that are unique and the subject of the contract may have already perished at the time of the conclusion of the contract and before the risk of loss passed to the buyer. In this exceptional case, Article 79 may apply as long as the seller had no knowledge of the prior 
Alemanha ("BGH"), ao julgar o Caso Vine Wax, considerado como o leading case do Artigo 79, afirmou que "the [CISG] does not distinguish between an untimely delivery and a delivery of goods not in conformity with the contract. For both breaches of contract the same standard of liability applies"19.

Para que a exoneração aconteça, o devedor deve ser capaz de provar a adequação de seu caso a inúmeros requisitos. Nesse capítulo será analisado o Artigo 79 da CISG: os requisitos para sua aplicação, a presença de um fornecedor na cadeia contratual da parte inadimplente, a notificação de exclusão de responsabilidade e os efeitos de sua aplicação ao caso concreto.

\subsection{Requisitos do Artigo 79(1)}

Diz o artigo 79 (1) da Convenção que:

“Artigo 79:

(1) A parte não é responsável pelo inadimplemento de qualquer de suas obrigações se for capaz de provar que tal inadimplemento se deu em função de um impedimento fora de seu controle e não era razoável esperar fosse levado em

destruction and could not reasonably have been expected to take the destruction of the goods into account at the time of the conclusion of the contract." [CISG-AC Opinion No. 7, "Exemption of Liability for Damages under Article 79 of the CISG", Rapporteur: Professor Alejandro M. Garro, Columbia University School of Law, New York, N.Y., USA. Adotado pela CISG-AC na $11^{\text {a }}$ reunião, em Wuhan, República Popular da China, em 12 de Outubro de 2007 disponível em http://www.cisg.law.pace.edu/cisg/CISG-AC-op7.html].

Sobre a exoneração da responsabilidade do vendedor através da aplicação do Artigo 79 da CISG, imaginamos um caso no qual um exportador (trader) de café, enviou um container cheio de sacas de café de uma safra específica, de Guaxupé para o Porto de Santos. No entanto, no caminho, violaram o lacre do container e a carga foi trocada por pedras. Isso ocorreu antes que responsabilidade pela mercadoria passasse às mãos do comprador, uma vez que a venda era FOB Santos. O vendedor só descobriu que a mercadoria vendida estava defeituosa quando ela chegou ao seu destino final na Europa. Como a venda era adstrita a uma safra específica de café, mais cara em função de sua excepcional qualidade, o vendedor não conseguiria obter bens substitutos no mercado e teria que ser exonerado da responsabilidade de indenizar o comprador, vez que o roubo das sacas de café constitui impedimento além de sua esfera de controle.

${ }^{19}$ Caso Vine Wax, disponível em http://cisgw3.law.pace.edu/cases/990324g1.html. 
consideração no momento da conclusão do contrato, ou que fosse evitado ou superado, ou ainda, que fossem evitadas ou superadas suas consequências. "20

Esse artigo estabelece quatro requisitos que devem ser necessariamente preenchidos, de forma cumulativa, para que possa haver a exclusão da responsabilidade da parte inadimplente na CISG: (1) o inadimplemento deve ser causado por um impedimento que esteja além do controle do devedor; (2) o impedimento deve ser imprevisível no momento da formação do contrato; e (3) o impedimento deve ser impossível de ser evitado ou deve ser impossível superar suas consequências. Além disso, (4) o impedimento que se adequa a esses requisitos deve ser a única causa do inadimplemento.

O devedor que alega uma exclusão de responsabilidade pelo inadimplemento deve ser capaz de provar que a situação se adequa a esses quatro requisitos estabelecidos pelo artigo 79(1) da Convenção, caso contrário será responsabilizado por tal inadimplemento. Ou seja, o ônus de provar a adequação aos requisitos é da parte que visa a aplicação do $\operatorname{artigo}^{21}$.

\footnotetext{
${ }^{20}$ Tradução livre do texto original, em inglês: "Article 79 (1) A party is not liable for a failure to perform any of his obligations if he proves that the failure was due to an impediment beyond his control and that he could not reasonably be expected to have taken the impediment into account at the time of the conclusion of the contract or to have avoided or overcome it or its consequences."

${ }^{21}$ LOOKOFSKY, Joseph; "Article 79, Liability Exemptions for Failure to Perform; excerpt from The 1980 United Nations Convention on Contracts for the International Sale of Goods", disponível em http://www.cisg.law.pace.edu/cisg/text/secomm/secomm-79.html.

Nesse sentido, também, Schwenzer: "The wording and purpose of Article 79 clearly indicate that the promisor must prove that an exempting impediment exists. The same applies where the impairment to performance is due to the conduct of a third person within the meaning of Article 79(2)" [SCHELECHTRIEM, Peter e SCHWENZER, Ingeborg, "Commentary on the UN

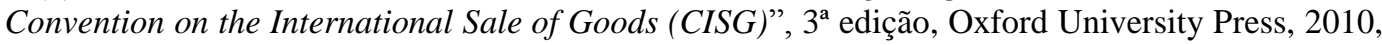
p. 1087].
} 


\subsubsection{Impedimento além do controle da parte inadimplente.}

Ao analisar o primeiro requerimento do Artigo 79(1), "impedimento fora do controle" do devedor da obrigação, há duas questões a serem analisadas: (1) o que se entende por "impedimento"; e (2) o que é considerado "fora do controle" do devedor da obrigação.

(1) O que se entende por "impedimento". Em seu Artigo 79(1), a CISG estabelece como um dos pré-requisitos para a exoneração de responsabilidade, que a falha em cumprir com as obrigações contratuais ocorra em função de um "impedimento". A ULIS (Legislação Uniforme sobre a Compra e Venda Internacional de Mercadorias) ${ }^{22}$, legislação uniforme que precedeu à CISG, utilizava a expressão "circunstâncias" em seu Artigo 74(1), para tratar do mesmo tema. O uso da palavra "impedimento" foi uma tentativa de evitar a imprecisão gerada pelo termo utilizado na ULIS e formular um critério mais objetivo ${ }^{23}$.

Ao adotar tal palavra, a CISG criou um sistema próprio, que visa enfatizar a natureza objetiva do evento perturbador, em detrimento do

\footnotetext{
${ }^{22}$ A Legislação Uniforme sobre a Compra e Venda Internacional de Mercadorias (ULIS - Uniform Law on the International Sale of Goods) é uma Convenção criada pelo UNIDROIT em 1964, com o objetivo de criar uma legislação internacional uniforme sobre compra e venda de mercadorias. Junto com a ULF (Convention relating to a Uniform Law on the Formation of Contracts for the International Sale of Goods), foi a base para a criação da CISG.

${ }^{23}$ NICHOLAS, Barry in "Force Majeure and Frustration": 27 American Journal of Comparative Law (1979"), pp. 231-245; disponível em http://www.cisg.law.pace.edu/cisg/biblio/nicholas.html.

Nesse sentido, John Honnold afirma que: "The crucial change was to extend exemption to situations where non-performance "was due to circumstances..." "Circumstances" could include a drastic change in costs or other economic conditions. In addition it could be argued that a seller could be freed from liability for defects in the goods that did not result from the seller's fault; (...) UNCITRAL and Impediments. UNCITRAL faced this issue and replaced "circumstances" by "impediment" - a word that (like "obstacles") implies a barrier to performance, such as delivery of the goods or transmission of the price rather than an aspect personal to the seller's performance" [HONNOLD, John, "Uniform Law for International Sales Under the 1980 United Nations Convention"; $\quad 3^{\mathrm{a}} \quad$ edição $\quad$ (1999), disponível em http://www.cisg.law.pace.edu/cisg/biblio/honnold.html].
} 
aspecto subjetivo $^{24}$. O sistema criado pela Convenção não é conectado a nenhum direito nacional em específico, de forma que a interpretação do direito interno de um país não ajudará na compreensão do conceito de "impedimento" estabelecido na referida lei. No entanto, a CISG não define o termo "impedimento" e, portanto, a interpretação do Artigo 79 pode se tornar difícil, uma vez que não se pode recorrer aos direitos nacionais para $\operatorname{tanto}^{25}$.

O caráter restritivo do texto do Artigo 79 cria um ambiente seguro para as trocas internacionais e obriga as partes a preverem situações que podem interferir no cumprimento contratual, de forma a negociar a alocação de riscos. Contratos internacionais são, frequentemente, contratos que se estendem durante muitos anos, e envolvem uma série de transações baseadas na relação entre as partes. Porque de longa duração, há um risco grande de esses contratos serem estremecidos por uma série de mudanças políticas e econômicas. Para concluir tais contratos, as partes necessitam de alguma garantia de estabilidade. Por ser restritivo, o Artigo 79 incentiva as partes a estabelecerem no contrato quais mudanças nas circunstâncias políticas e econômicas darão azo à renegociação ou modificação do contrato. A inserção desses termos no contrato garante o cumprimento contratual, de forma que o objetivo da CISG de sempre proteger o cumprimento dos contratos é promovido pelo Artigo $79^{26}$.

\footnotetext{
${ }^{24}$ TALLON, Denis in "Commentary on the International Sales Law: The 1980 Vienna Sale Convention”, Cesare Massimo Bianca \& Michael Joachim Bonell, eds., Milan (1987), p. 579; disponível em: http://www.cisg.law.pace.edu/cisg/biblio/tallon-bb79.html.

25 TALLON, Denis in "Commentary on the International Sales Law: The 1980 Vienna Sale Convention”, Cesare Massimo Bianca \& Michael Joachim Bonell, eds., Milan (1987), p. 579; disponível em: http://www.cisg.law.pace.edu/cisg/biblio/tallon-bb79.html.

${ }^{26}$ SPIVACK, Carla; "Of Shrinking Sweatsuits and Poison Vine Wax: A Comparison of Excuse for Nonperformance under the UCC and the CISG"; Oklahoma City University, pp. 4 e 6, disponível em http://law.bepress.com/expresso/eps/1219.
}

Nessa parte, a autora cita: SMYTHE, Donald J., "Bounded Rationality, The Doctrine of Impracticability, and the Governance of Relational Contract"s, 13S. Cal. Interdisc. L. J. 227, 230233 (2004) e SALACUSE, Jeswald W., "Renegotiating International Business Transactions: The Continuing Strugle of Life Against Form”, 35 Intllaw 1507, 1509 (2001). 
O termo utilizado pelo Artigo 79(1) cobre apenas eventos que de fato impedem o cumprimento da obrigação ${ }^{27}$. Em regra, não cobre as circunstâncias supervenientes ao contrato que tornam mais oneroso o seu cumprimento para uma das partes, conhecidas como hardship ${ }^{28}$. Os típicos

${ }^{27}$ SPIVACK, Carla; “Of Shrinking Sweatsuits and Poison Vine Wax: A Comparison of Excuse for Nonperformance under the UCC and the CISG"; Oklahoma City University, p. 15, disponível em http://law.bepress.com/expresso/eps/1219.

SCHELECHTRIEM, Peter e SCHWENZER, Ingeborg, "Commentary on the UN Convention on

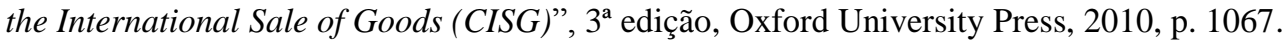

FLAMBOURAS, Dyonisios, In: FELEMEGAS, John, "An International Approach to the Interpretation of the United Nations Convention on Contracts for the International Sale of Goods (1980) as Uniform Sales Law", Cambridge University Press 2007, pp. 499-505.

Nas palavras de Joseph Lookofsy: “(...)a party can never be granted an Article 79 exemption unless he (also) shows that the 'impediment' in question lies 'beyond his control', and this requirement alone reduces the possibility of a non-conformity exemption to something near nil." [LOOKOFSKY, Joseph; "Article 79, Liability Exemptions for Failure to Perform; excerpt from The 1980 United Nations Convention on Contracts for the International Sale of Goods", disponível em http://www.cisg.law.pace.edu/cisg/text/secomm/secomm-79.html].

Nas palavras de John Honnold: “As we have seen (\$427, supra), paragraph 1 of Article 79 embodies a decision that exemption from liability for a "failure to perform" should be confined to situations in which an "impediment" prevents performance-production or delivery of goods, transfer of funds to pay the price. Paragraph 1 also emphasizes that grounds for excusing failure to perform are strict" [HONNOLD, John, "Uniform Law for International Sales Under the 1980 United Nations Convention"; $3^{\text {a }}$ edição (1999), disponível em http://www.cisg.law.pace.edu/cisg/biblio/honnold.html].

No entanto, há autores que afirmam que o termo "impedimento" deve ser interpretado de forma mais flexível, para abarcar eventos que não só impeçam o cumprimento do contrato, mas que o tornem difícil de ocorrer. [RIMKE, Joern, "Force majeure and hardship: application in international trade practice with specific regard to the CISG and the UNIDROIT Principles of International Commercial Contracts." disponível em: http://www.cisg.law.pace.edu/cisg/biblio/rimke.html; NICHOLAS, Barry, "Impracticability and Impossibility in the U.N. Convention for the International Sale of Goods". disponível em http://www.cisg.law.pace.edu/cisg/biblio/nicholas1.html].

28 “(...) hardship consiste em situação de desequilíbrio das prestações contratuais ajustadas, experimentada por um contratante, em virtude da ocorrência de fatos alheios à sua vontade, imprevisíveis e supervenientes à celebração do contrato. Instituto criado no contexto do comércio internacional, o hardship foi sistematizado nos arts. 6.2.1 a 6.2.3 dos Princípios do UNIDROIT relativos aos Contratos do Comércio Internacional. O instituto de hardship equivale à teoria da onerosidade excessiva, disciplinada pelos arts. 478, 479 e 317 do nosso Código Civil os quais, sistematicamente interpretados, disciplinam a resolução e a revisão contratual em situações de desequilíbrio da equação econômica estabelecida pelas partes" [GAMA JR., Lauro, "Hardship nos contratos internacionais: o papel revigorante dos Princípios do UNIDROIT na evolução da Convenção de Viena", Publicado na Revista Trimestral de Direito Civil, ano 11, jul/set 2010, p. 205/229]. Não há, na CISG, regra expressa sobre a possibilidade de revisão contratual com base em hardship. Por isso, como já dito acima, alguns autores defendem a aplicação dos Princípios do UNIDROIT para modernizar a interpretação da Convenção e incluir tais situações em seu escopo 
casos de força maior, como terremoto, raio, enchente, incêndio, tempestades, entre outros, serão normalmente considerados como impedimentos. Porém, deve ser analisado se o fenômeno natural era previsível. Em alguns mercados, por exemplo, é comum que chuvas fortes interrompam a produção de alguma fruta em determinada época do ano. Nesses casos, o fenômeno natural não poderá ser considerado como um impedimento ${ }^{29}$.

Intervenções estatais (fait $d u$ prince), normalmente também serão consideradas como impedimentos. No entanto, afirma Schwenzer que alguns tribunais arbitrais, tais como os russos e os chineses, tem o entendimento mais restritivo quanto a tais intervenções, e outros alegam que tais acontecimentos poderiam ser previstos no momento da formação do contrato. Portanto, afirma a autora que as partes devem estipular a alocação de riscos no contrato no que concerne a intervenções estatais, principalmente no que diz respeito a licenças de importação e exportação ${ }^{30}$.

Quanto a mudanças econômicas, existe uma dúvida geral na doutrina para saber se constituem ou não um impedimento. A CISG não inclui em seu texto, nenhum artigo sobre hardship, ou onerosidade excessiva. Alguns

de aplicação. Já há decisões arbitrais e judiciais nesse sentido, que incorporam o hardship na CISG através de seu artigo 7, tal como a decisão da Cour de Cassation Belga que reconheceu tal possibilidade em uma decisão de 2009 [19 de junho de 2009, Cour de Cassation Scafom International BV v. Lorraine Tubes S.A.S, disponível em http://cisgw3.law.pace.edu/cases/090619b1.html].

Article 7:

"(1) In the interpretation of this Convention, regard is to be had to its international character and to the need to promote uniformity in its application and the observance of good faith in international trade.

(2) Questions concerning matters governed by this Convention which are not expressly settled in it are to be settled in conformity with the general principles on which it is based or, in the absence of such principles, in conformity with the law applicable by virtue of the rules of private international law."

${ }^{29}$ SCHELECHTRIEM, Peter e SCHWENZER, Ingeborg, "Commentary on the UN Convention on the International Sale of Goods (CISG)”, $3^{\mathrm{a}}$ edição, Oxford University Press, 2010, p. 1070.

${ }^{30}$ SCHELECHTRIEM, Peter e SCHWENZER, Ingeborg, "Commentary on the UN Convention on the International Sale of Goods (CISG)”, $3^{\mathrm{a}}$ edição, Oxford University Press, 2010, p. 1071. 
autores entendem que o Artigo 79(1) deve ser interpretado de forma a abarcar tal possibilidade, considerando-a como um impedimento ao cumprimento do contrato. No entanto, não há consenso doutrinário quanto à tal possibilidade. Da mesma forma, os autores que entendem que o Artigo 79(1) se aplica a casos de onerosidade excessiva não convergem quanto ao grau de severidade nas mudanças nas circunstâncias econômicas necessário para ser considerado um impedimento. Por isso, não entraremos a fundo nessa discussão ${ }^{31}$.

É importante ressaltar que os eventos citados não constituem impedimentos per se. A caracterização de um impedimento, nos termos do Artigo 79, depende das circunstâncias de cada caso concreto, pois ele deve ser externo ao devedor. Por exemplo, um incêndio que leva à destruição da fábrica do vendedor não o exonerará de suas obrigações se ele falhou em tomar as medidas preventivas contra incêndio, necessárias para a operação de uma fábrica.

Em uma fábrica de microchips, por exemplo, incêndios não são acontecimentos raros, vez que os materiais utilizados são altamente inflamáveis ${ }^{32}$. Em fábricas com alto risco de incêndio, deve haver um

\footnotetext{
${ }^{31}$ SCHELECHTRIEM, Peter e SCHWENZER, Ingeborg, "Commentary on the UN Convention on the International Sale of Goods (CISG)”, 3ª edição, Oxford University Press, 2010, p. 1076.

SPIVACK, Carla; "Of Shrinking Sweatsuits and Poison Vine Wax: A Comparison of Excuse for Nonperformance under the UCC and the CISG"; Oklahoma City University, p. 16, disponível em http://law.bepress.com/expresso/eps/1219.

CISG-AC Opinion No. 7, "Exemption of Liability for Damages under Article 79 of the CISG", Rapporteur: Professor Alejandro M. Garro, Columbia University School of Law, New York, N.Y., USA. Adotado pela CISG-AC na $11^{a}$ reunião, em Wuhan, República Popular da China, em 12 de Outubro de 2007 disponível em http://www.cisg.law.pace.edu/cisg/CISG-AC-op7.html.

ALMEIDA PRADO, Maurício; "Interpretação e aplicação da regra de "Exoneração" da Convenção de Viena (1980)", p. 2. Esse estudo foi inicialmente publicado no livro "Arbitragem Internacional - UNCITRAL, CISG e Direito Brasileiro”, São Paulo, Quartier Latin, 2010.

32 SHERIN, Brian, "Comprehensive risk management for IC fabs", disponível em: http://www.electroiq.com/articles/sst/print/volume-41/issue-2/departments/news/comprehensiverisk-management-for-ic-fabs.html.
} 
completo sistema contra fogo, com o poder de evitar ou minimizar ao máximo os danos causados por tal acontecimento. Em tais circunstâncias, caso um incêndio cause danos aos credores do dono da fábrica e constate-se que as medidas preventivas não foram devidamente tomadas, o acidente não restará fora da esfera de controle do devedor. Tal ocorre pois, caso o dono da fábrica tivesse instalado sistema contra fogo, os danos causados pelo incêndio seriam minimizados ou até mesmo evitados. Nesse caso, a diligência é exigível pois a atividade exercida apresenta alto risco de incêndio, de forma que esse acontecimento só será considerado como um impedimento, nos termos da CISG, caso todas as medidas preventivas sejam devidamente implementadas e, ainda assim, ocorram graves danos em função de incêndio (essa situação se relaciona ao requisito de impossibilidade de evitar o impedimento ou de prevenir suas consequências, item 1.1.3) ${ }^{33}$. Percebe-se que a análise do impedimento está sempre adstrita às circunstâncias do caso concreto e especificidades do mercado em questão.

\section{(2) O que é considerado "fora do controle" do devedor da} obrigação. A interpretação da cláusula de exoneração presente na CISG deve levar em consideração o conceito fundamental de que a execução do contrato é obstada por um impedimento que não pode ser controlado pelo devedor da obrigação ${ }^{34}$. Somente circunstâncias objetivas, que se

FM Global, "Safeguarding the Semiconductor Fabrication Facility", disponível em: http://www.cemag.us/article/safeguarding- semiconductor-fabrication-facility.

CNA, "Electronic Component and Hardware Manufacturing Industry", Risk Control, Industry Guide Series, 2008 disponível em: http://www.cna.com/vcm content/CNA/internet/ Static\%20File\%20for\%20Download/Risk\%20Control/Industry\%20Guide\%20Series/ElectronicCo mponenent\&HdweMfg.pdf.

${ }^{33}$ FLAMBOURAS, Dionysios P., "The Doctrines of Impossibility of Performance and clausula rebus sic stantibus in the 1980 Vienna Convention on Contracts for the International Sale of Goods and the Principles of European Contract Law: A Comparative Analysis" disponível em http://www.cisg.law.pace.edu/cisg/biblio/flambouras1.html.

${ }^{34}$ SCHELECHTRIEM, Peter e SCHWENZER, Ingeborg "Commentary on the UN Convention on the International Sale of Goods (CISG)”, $3^{\mathrm{a}}$ edição, Oxford University Press, 2010, p.1067. 
encontrem fora da esfera de controle do devedor poderão ser consideradas como um evento capaz de levar à exoneração, nos termos do Artigo $79^{35}$.

Ou seja, apenas eventos externos ao devedor da obrigação poderão constituir um "impediment" na CISG. Deve ser feita uma distinção entre aquilo que se encontra na esfera de risco do devedor, e aquilo que é externo a ele. Para tanto, deve ser analisada a alocação de riscos feita no contrato, os usos e costumes do mercado em questão e a esfera de risco típica do devedor da obrigação.

A exigência de que o evento perturbador esteja fora da esfera de controle do devedor da obrigação está baseada na suposição de que sempre há uma esfera típica de controle, dentro da qual é razoável esperar que o devedor assuma e controle os riscos inerentes ao negócio ${ }^{36}$. Estará dentro de sua esfera de risco típica as circunstâncias que têm origem no próprio devedor, como sua capacidade financeira, a responsabilidade por seus próprios funcionários, a capacidade de seus fornecedores entregarem matéria prima no tempo acordado, a correta organização de etapas necessárias ao cumprimento do contrato, etc ${ }^{37}$.

Segundo Schlechtriem, os termos do contrato normalmente irão determinar o limite pelo qual o devedor se obrigou a evitar eventos perturbadores ao cumprimento do contrato e que restam fora de sua esfera

\footnotetext{
${ }^{35}$ FLAMBOURAS, Dionysios P., "The Doctrines of Impossibility of Performance and clausula rebus sic stantibus in the 1980 Vienna Convention on Contracts for the International Sale of Goods and the Principles of European Contract Law: A Comparative Analysis" disponível em http://www.cisg.law.pace.edu/cisg/biblio/flambouras1.html.

${ }^{36}$ LIU, Chengwei, "Force Majeure - Perspectives from the CISG, UNIDROIT Principles, PECL and Case Law" [2 $2^{\mathrm{a}}$ edição Case annotated update (April 2005)], disponível em http://www.cisg.law.pace.edu/cisg/biblio/liu6.html\#fm119. Nesse sentido, o autor cita STOLL, Hans, em "Commentary on the U.N. Convention on the International Sale of Goods (CISG)", $2^{\mathrm{a}}$ edição, Peter Schlechtriem, Geoffrey Thomas trans. (1998); p. 610.

${ }^{37}$ SCHELECHTRIEM, Peter e SCHWENZER, Ingeborg "Commentary on the UN Convention on the International Sale of Goods (CISG)”, $3^{\mathrm{a}}$ edição, Oxford University Press, 2010, p. 1067.
} 
de controle. Garantias poderão aumentar o grau de responsabilidade do devedor, enquanto que ressalvas e exonerações poderão restringir os acontecimentos pelos quais o devedor se obriga. Porém, na ausência de tais disposições contratuais, as obrigações das partes devem ser interpretadas nos termos do Artigo 8 da CISG $^{38}$, de acordo com as intenções e expectativas de contratantes razoáveis, para que se entenda o risco contratual real assumido pelas partes contratantes ${ }^{39}$.

Portanto para que um evento seja considerado de fato um impedimento, nos termos do Artigo 79, ele deve estar fora da esfera de risco do devedor da obrigação. Não obstante isso, o devedor deverá provar que se adequa aos outros três requisitos para alcançar a exoneração da obrigação, e que serão analisados mais adiante nesta monografia.

\subsubsection{Impedimento imprevisível no momento da formação do contrato.}

O devedor da obrigação é responsável por eventos que se encontram fora da sua esfera de controle se ele pudesse prever tais acontecimentos no momento da formação do contrato. O requisito da imprevisibilidade é entendido como o mais difícil de ser provado, pois eventos como guerras,

\footnotetext{
${ }^{38}$ Artigo 8:

"(1) For the purposes of this Convention statements made by and other conduct of a party are to be interpreted according to his intent where the other party knew or could not have been unaware what that intent was.

(2) If the preceding paragraph is not applicable, statements made by and other conduct of a party are to be interpreted according to the understanding that a reasonable person of the same kind as the other party would have had in the same circumstances.

(3) In determining the intent of a party or the understanding a reasonable person would have had, due consideration is to be given to all relevant circumstances of the case including the negotiations, any practices which the parties have established between themselves, usages and any subsequent conduct of the parties."

39 SCHLECHTRIEM, Peter, "Uniform Sales Law - The UN-Convention on Contracts for the International Sale of Goods" disponível em http://www.cisg.law.pace.edu/cisg/biblio/schlechtriem-79.html.
} 
incêndios e tempestades já aconteceram no passado e podem acontecer novamente no futuro ${ }^{40}$.

Frequentemente, as partes de um contrato preveem a possibilidade de ocorrência de algum impedimento ao cumprimento do contrato ${ }^{41}$. Algumas vezes, há menção expressa no contrato no sentido de que a ocorrência de alguns eventos irá exonerar uma das partes das consequências de um inadimplemento. Outras vezes, tal exoneração ou, ao contrário, a obrigação de adimplir o contrato apesar da ocorrência de certo evento, ficam claras

\footnotetext{
${ }^{40}$ Nesse sentido, o Comentário do Secretariado da UNCITRAL afirma que: "It is this later element which is the most difficult for the non-performing party to prove. All potential impediments to the performance of a contract are foreseeable to one degree or another. Such impediments as wars, storms, fires, government embargoes and the closing of international waterways have all occurred in the past and can be expected to occur again in the future." [GUIDE TO CISG ARTICLE 79, Secretariat Commentary (closest counterpart to an Official Commentary), disponível em http://www.cisg.law.pace.edu/cisg/text/secomm/secomm-79.html].

41 "Over the course of the past decades, the United Nations Economic Commission for Europe (ECE) has supervised and finalized the work of representatives of sellers and buyers and of governmental representatives in preparing general conditions of sale (standard contracts) for a wide variety of transactions. All of these contracts contain provisions on exemption from liability when performance has been prevented by a supervening impediment.
}

One of the important ECE General Conditions covers the Supply of Plant and Machinery for Export (No. 188); this version was prepared for transactions among countries with market economies. The contract terms on exemption (or "reliefs") are as follows:

\begin{abstract}
General Conditions (ECE) No. $188[13]$
"10. RELIEFS

"10.1. The following shall be considered as cases of relief if they intervene after the formation of the Contract and impede its performance: industrial disputes and any other circumstances (e.g., fire mobilization, requisition, embargo, currency restrictions, insurrection, shortage of transport, general shortage of materials and restrictions in the use of power) when such other circumstances are beyond the control of the parties.
\end{abstract}

"10.2. The party wishing to claim relief by reason of any of the said circumstances shall notify the other party in writing without delay on the intervention and on the cessation thereof.

"10.3 The effects of the said circumstances, so far as they affect the timely performance of their obligations by the parties, are defined in Clauses 7 and 8. Save as provided in paragraphs 7.5., 7.7., and 8.7., if, by reason of any of the said circumstances, the performance of the Contract within a reasonable time becomes impossible, either party shall be entitled to terminate the Contract by notice in writing to the other party without requiring the consent of any Court...."

[HONNOLD, John, "Uniform Law for International Sales Under the 1980 United Nations Convention"; $\quad 3^{\mathrm{a}} \quad$ edição (1999), $\quad$ disponível em http://www.cisg.law.pace.edu/cisg/biblio/honnold.htmll. 
através da análise do contexto do contrato ${ }^{42}$. Em ambos os casos, o Artigo 6 da CISG garante a validade de tais manifestações contratuais (explícitas ou implícitas $)^{43}$.

Caso o devedor da obrigação não tenha feito nenhuma reserva quanto a um impedimento previsível no momento da formação do contrato, entende-se que ele assumiu o risco de sua realização. O teste relevante, nesses casos, é o da pessoa razoável. Temos que analisar se uma pessoa razoável, no lugar do devedor, sob as mesmas circunstâncias em que ele se encontrava ao tempo da conclusão do contrato e de acordo com as práticas do mercado em questão, conseguiria ter previsto o impedimento alegado pelo devedor ${ }^{44}$.

\footnotetext{
${ }^{42}$ GUIDE TO CISG ARTICLE 79, Secretariat Commentary (closest counterpart to an Official Commentary), disponível em http://www.cisg.law.pace.edu/cisg/text/secomm/secomm-79.html.

${ }^{43}$ Quando as partes estabelecem cláusulas de exoneração de responsabilidade diferentes do que está estipulado no Artigo 79 da CISG, é entendido que as partes derrogaram ou alteraram o efeito desse artigo, o que é possível em função do Artigo 6 da Convenção:
}

"Article 6

The parties may exclude the application of this Convention or, subject to article 12, derogate from or vary the effect of any of its provisions."

Sobre isso, afirma Joseph Lookofsky que: "Of course, before one proceeds to apply the gap-filling rules, one needs to ask whether the basis of a given promisor's liability for non-performance is regulated by the parties' agreement. For although it is rare that the express terms of a sales contract provide for absolute liability (i.e., for any breach, without exemption/exception), many sales contracts contain a force majeure clause or equivalent. Clauses limiting the seller's liability to instances of (grossly) negligent breach are also quite common, especially when coupled with an obligation to repair or replace" [LOOKOFSKY, Joseph, "Article 79, Liability Exemptions for Failure to Perform; excerpt from The 1980 United Nations Convention on Contracts for the International Sale of Goods", disponível em http://www.cisg.law.pace.edu/cisg/text/secomm/secomm-79.html].

${ }^{44}$ SCHELECHTRIEM, Peter e SCHWENZER, Ingeborg "Commentary on the UN Convention on the International Sale of Goods (CISG)", $3^{\mathrm{a}}$ edição, Oxford University Press, 2010, p. 1068.

LAMAUD, Emmanuel, "Comparison Between the CENTRAL List and the Vienna Convention for the International Sale of Goods - Specific Topics (research paper 2006)”, disponível em http://www.trans-lex.org/850000.

RIMKE, Joern, "Force majeure and hardship: application in international trade practice with specific regard to the CISG and the UNIDROIT Principles of International Commercial Contracts", disponível em http://www.cisg.law.pace.edu/cisg/biblio/rimke.html.

LEE, Wanki, "Exemptions of Contract Liability Under the 1980 United Nations Convention", disponível em http://www.cisg.law.pace.edu/cisg/biblio/lee.html. 
O parâmetro do que é razoável de se prever é diferente entre transações domésticas e internacionais. Afirma Carla Spivack, ao analisar a diferença entre a CISG e Código Comercial Uniforme dos EUA (UCC), que comerciantes que participam de transações internacionais rotineiramente são capazes de antecipar uma gama de acontecimentos muito maior do que aqueles que lidam apenas com trocas domésticas. Tribunais que aplicam a CISG assumem que as partes de um contrato transnacional estão cientes da possibilidade de mudança de leis e regulações nos países de seus parceiros comerciais $^{45}$. Por isso, ao se analisar contratos internacionais regulados pela Convenção, deve-se levar em consideração um parâmetro mais abrangente de acontecimentos previsíveis em comparação a contratos regulados pela legislação nacional. No entanto, a análise final a respeito da previsibilidade de um evento que impede o cumprimento contratual somente poderá ser feita pelo julgador, na condução de cada caso concreto ${ }^{46}$.

\footnotetext{
Nesse sentido, afirma Denis Tallon que: "The impediment must be reasonably foreseeable. The reference is thus the reasonable person, the bon père de famille, in accordance with the general concept of the Convention, i.e., halfway between the inveterate pessimist who foresees all sorts of disasters and the resolute optimist who never anticipates the least misfortune." [TALLON, Denis in "Commentary on the International Sales Law: The 1980 Vienna Sale Convention", Cesare Massimo Bianca \& Michael Joachim Bonell, eds., Milan (1987), p. 574; disponível em http://www.cisg.law.pace.edu/cisg/biblio/tallon-bb79.html].
}

${ }^{45}$ SPIVACK, Carla; "Of Shrinking Sweatsuits and Poison Vine Wax: A Comparison of Excuse for Nonperformance under the UCC and the CISG", p.19, Oklahoma City University, disponível em http://law.bepress.com/expresso/eps/1219.

Nesse sentido, afirma Joseph Lookofsky que: “(...) assuming the parties' contract is silent on the issue of increased cost, the obligor's inability to make a profit on a particular contract will not, in and of itself; lead to a liability exemption under the CISG. This is because price increases, even dramatic ones, are generally foreseeable; put another way, those who sell goods on a long-term basis are in the 'business' of assuming this kind of risk" [LOOKOFSKY, Joseph," Article 79, Liability Exemptions for Failure to Perform; excerpt from The 1980 United Nations Convention on Contracts for the International Sale of Goods", disponível em http://www.cisg.law.pace.edu/cisg/text/secomm/secomm-79.html].

\footnotetext{
${ }^{46}$ Nesse sentido, afirma o Comentário do Secretariado que “ (...) where neither the explicit nor the implicit terms of the contract show that the occurrence of the particular impediment was envisaged, it is necessary to determine whether the non-performing party could reasonably have been expected to take it into account at the time of the conclusion of the contract. In the final analysis this determination can only be made by a court or arbitral tribunal on a case-by-case basis" [GUIDE TO CISG ARTICLE 79, Secretariat Commentary (closest counterpart to an Official Commentary), disponível em http://www.cisg.law.pace.edu/cisg/text/secomm/secomm79.html].
} 


\subsubsection{Impedimento impossível de se evitar ou com consequências impossíveis de serem evitadas ou superadas.}

Um impedimento imprevisível ao devedor no momento da conclusão do contrato pode não ser capaz de exonerá-lo da obrigação caso seja razoável esperar dele que tal impedimento seja evitado ou que suas consequências sejam evitadas ou superadas. Afirma Schwenzer que esse requerimento, ao ser aplicado no comércio internacional, deve ser bastante restritivo. Via de regra, o devedor deve superar as consequências de um impedimento até mesmo quando isso resultar em grande aumento de custos ou em prejuízo decorrente da transação ${ }^{47}$.

Dependendo das circunstâncias de cada caso concreto, o devedor pode ser obrigado a oferecer um produto substituto que satisfará o contrato de modo semelhante. Da mesma forma, poderá ser razoável para o devedor considerar outras opções de transporte que possam gerar grande aumento de custos transacionais ou até mesmo pagar um preço a seu fornecedor muito superior ao preço acordado com seu cliente ${ }^{48}$.

A extensão e natureza dos esforços que podem ser razoavelmente esperados do devedor para satisfazer esse terceiro requisito imposto pela

\footnotetext{
${ }^{47}$ SCHELECHTRIEM, Peter e SCHWENZER, Ingeborg "Commentary on the UN Convention on the International Sale of Goods (CISG)”, 3 edição, Oxford University Press, 2010, p. 1069.

${ }^{48}$ Nesse sentido, afirma Flambouras que: "Even an unforeseeable impediment exempts the nonperforming party only if he can prove that he could neither avoid the impediment, nor by taking reasonable steps, overcome its consequences. Avoidance should take place in the most effective manner from an economic point of view, that is, with conclusion of an insurance contract (if this is the norm and it is available), with the insertion of special clauses in the contract of sale, or with the adaptation of the price in order to reflect assumption of the risks by the seller or the buyer. Again, reference should be made to the reasonable person, and a case-by-case analysis will be necessary. For example, in an earthquake zone the effects of earthquakes can be overcome by special construction techniques, though it would be different in the case of a quake of much greater force than usual." [FLAMBOURAS, Dionysios, "The Doctrines of Impossibility of Performance and clausula rebus sic stantibus in the 1980 Vienna Convention on Contracts for the International Sale of Goods and the Principles of European Contract Law: A Comparative Analysis", disponível em: http://www.cisg.law.pace.edu/cisg/biblio/flambouras1.html].
} 
CISG deve ser estabelecida, novamente, de acordo com a alocação de riscos do contrato. Caso não exista tal alocação de riscos, a regra geral é de que o devedor será exonerado somente se o chamado "limite de sacrifício" for excedido $^{49}$. Nesse sentido, afirma Huber que " $[A] s$ a rule, it is suggested that the seller will only be excused where extraordinary expense and effort would be required in order to overcome the impediment" ${ }^{\prime 50}$.

Dessa forma, percebe-se que o conceito de "razoabilidade" inserido no Artigo 79 é restritivo. De fato, está expresso no Comentário do Secretariado da UNCITRAL, o texto mais próximo de um comentário oficial sobre a interpretação da CISG, que “(...) a party who is under an obligation to act must do all in his power to carry out his obligation (....",51.

É importante ressaltar, ainda, que quando o contrato envolve a compra e venda de bens genéricos, para os quais existe um mercado estabelecido, o vendedor assume o risco de procurar esses bens no mercado. Esse risco é o que os doutrinadores denominam de "procurement risk", Desde que bens substitutos estejam disponíveis no mercado, o vendedor deve exaurir todas as possibilidades de adquirir tais bens, sem exceder o referido "limite de sacrifício".

Na compra e venda de bens específicos, provenientes de determinado lote ou estoque, o risco do vendedor de obter os bens está adstrito, por óbvio, a tal lote ou estoque. O vendedor estará exonerado caso um evento

\footnotetext{
${ }^{49}$ SCHELECHTRIEM, Peter e SCHWENZER, Ingeborg, "Commentary on the UN Convention on the International Sale of Goods (CISG)”, 3ª edição, Oxford University Press, 2010, p. 1069.

50 HUBER, Peter; MULLIS, Alastair, "The CISG: A New Textbook for Students and Practitioners", Sellier, European Law Publishers, 2007, p. 262.

${ }^{51}$ GUIDE TO CISG ARTICLE 79, Secretariat Commentary (closest counterpart to an Official Commentary), in http://www.cisg.law.pace.edu/cisg/text/secomm/secomm-79.html.

${ }^{52}$ SCHELECHTRIEM, Peter e SCHWENZER, Ingeborg "Commentary on the UN Convention on the International Sale of Goods (CISG)”, 3 edição, Oxford University Press, 2010, p. 1074.
} 
imprevisível e inevitável atinja esses bens. Caso o evento atinja apenas parte do estoque ou lote em questão, o vendedor deverá realizar entregas parciais, dividindo o estoque ou lote de forma proporcional entre os compradores com os quais ele havia se obrigado ${ }^{53}$.

O "procurement risk" do vendedor é espelhado pelo que se denomina de "utility risk" do comprador. Este último não pode se recusar a receber os bens comprados em função de circunstâncias econômicas desfavoráveis, impossibilidade ou diminuição no preço de revenda, ou caso o uso inicialmente pensado para os bens já não esteja disponível ${ }^{54}$. Dessa forma, caso seja firmado um contrato de fornecimento de petróleo entre duas empresas, pelo prazo de cinco anos, com preço fixo por galão e, após dois anos, o preço do galão diminuir drasticamente no mercado, o comprador não poderá alegar a aplicação do Artigo 79 para exonerar-se da obrigação de pagar o preço inicialmente acordado.

Por fim, vale a pena ressaltar que de acordo com esse requisito, o devedor tem a obrigação de agir a partir do momento em que se torna possível prever o impedimento. Quando algum impedimento não é previsível no momento da formação do contrato, o requisito da previsibilidade estará preenchido. No entanto, se antes do tempo de entrega o impedimento torna-se previsível, o devedor deve agir para evitá-lo ou diminuir suas consequências ${ }^{55}$.

\footnotetext{
${ }^{53}$ SCHELECHTRIEM, Peter e SCHWENZER, Ingeborg "Commentary on the UN Convention on the International Sale of Goods (CISG)", $3^{\mathrm{a}}$ edição, Oxford University Press, 2010, p. 1074.

${ }^{54}$ SCHELECHTRIEM, Peter e SCHWENZER, Ingeborg "Commentary on the UN Convention on the International Sale of Goods (CISG)”, 3a edição, Oxford University Press, 2010, p. 1077.

55 ERIKSEN, Eivind (2004) "Terrorism and Force Majeure in International Contracts", Bond Law Review, Vol. 16, Iss. 2, Artigo 7, disponível em http://epublications.bond.edu.au/blr/vol16/iss2/7.
} 


\subsubsection{Impedimento como a causa exclusiva do inadimplemento.}

O último requerimento do Artigo 79 é que o impedimento imprevisível e insuperável seja a única razão para a quebra contratual. Quando há mais de um evento que impede o cumprimento do contrato, todos eles devem preencher os requisitos do Artigo 79 (impedimento além do controle do devedor, imprevisível e impossível de se evitar ou com consequências impossíveis de serem evitadas ou superadas). Nesse caso, se um dos eventos não se adequar aos requisitos do artigo, o devedor não será exonerado. Da mesma forma, o devedor não será exonerado caso o impedimento ocorra uma vez que ele já se encontre em mora ${ }^{56}$.

O último requerimento do Artigo 79 é de natureza lógica - a quebra contratual deve decorrer do impedimento alegado como fundamento da exoneração de responsabilidade ${ }^{57}$. O vendedor não pode, por exemplo, valer-se de um incêndio em seu armazém caso o mesmo tenha ocorrido após sua recusa em cumprir com o contrato. $\mathrm{O}$ inadimplemento é decorrente da recusa, e não do incêndio, ainda que tal incêndio fosse capaz de impedir o cumprimento do contrato caso a recusa não existisse.

Apesar de majoritário, tal entendimento não é pacífico. Há autores que divergem da abordagem apresentada e afirmam que o impedimento será suficiente para caracterizar a exoneração de responsabilidade quando, ignorados todos os acontecimentos que permeiam o inadimplemento, o evento apontado como impedimento for capaz de, por si só, causar a quebra contratual. Nesse sentido, afirmam Fritz Enderlein e Dietrich Maskow que: “(...) the impediment should in our view also be accepted when a cause

\footnotetext{
${ }^{56}$ SCHELECHTRIEM, Peter e SCHWENZER, Ingeborg "Commentary on the UN Convention on

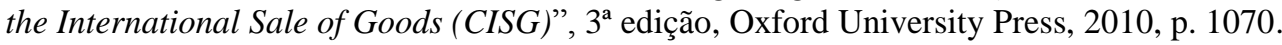

57 TALLON, Denis in "Commentary on the International Sales Law: The 1980 Vienna Sale Convention”, Cesare Massimo Bianca \& Michael Joachim Bonell, eds., Milan (1987), p. 574; disponível em: http://www.cisg.law.pace.edu/cisg/biblio/tallon-bb79.html.
} 
overtakes another cause ${ }^{\text {,58 }}$. Como defesa à tese, tais autores imaginam um caso em que bens embalados de forma imprópria pereçam em função de acidente no transporte. Apesar da falha na embalagem, apenas o acidente será considerado como impedimento à execução do contrato, pois é causa mais grave que supera a falha anterior ${ }^{59}$. No entanto, a maioria dos doutrinadores entende que o impedimento alegado pelo devedor deve ser a causa exclusiva do inadimplemento, de forma que o acidente no transporte não seria suficiente para justificar a aplicação do Artigo 79, em função da existência de outro evento que concorreu para o inadimplemento.

\subsubsection{A aplicação do Artigo 79 (2).}

O parágrafo segundo do Artigo 79 se destina a regular a situação na qual o inadimplemento de uma parte é devido à falha de uma terceira pessoa, incumbida pela parte inadimplente de cumprir o contrato inteiro ou parte dele. Nesse caso, a parte inadimplente será exonerada somente se ela

\footnotetext{
58 ENDERLEIN, Fritz e MASKOW, Dietrich, "International Sales Law, United Nations Convention on Contracts for the International Sale of Goods, Convention on the Limitation Period in the International Sale of Goods", Oceana Publications, 1992, disponível em http://www.cisg.law.pace.edu/cisg/biblio/enderlein.html\#art79.
}

\footnotetext{
${ }^{59}$ Há autores, como Chengwei Liu [LIU, Chengwei, "Force Majeure - Perspectives from the CISG, UNIDROIT Principles, PECL and Case Law" [2 edição: Case annotated update (April 2005)], disponível em http://www.cisg.law.pace.edu/cisg/biblio/liu6.html\#fm119.], Fritz Enderlein e Dietrich Maskow que discordam da abordagem apresentada. Nesse sentido, esses autores afirmam que: "Unlike Tallon $(B B, 583)$, we believe that it cannot be required that the impediment is the exclusive cause of a breach of contract. This is true not only of cases in which it covers the breach of contract only partially, but the impediment should in our view also be accepted when a cause overtakes another cause. In an example given by Tallon, improperly packed goods later perish because of an accident which constitutes an impediment. Tallon does not want to allow an exemption. We believe that it must be possible. It is only the damages which are affected by the exemption, and the damage to the buyer has not become worse because of the fact that the perished goods were packed improperly. (...) It is decisive, as we hold, whether the impediment lastly has caused the breach of contract. If this is so, it consumes other breaches of contract for which there are no grounds for exemption insofar as those no longer appear independently." [ENDERLEIN, Fritz e MASKOW, Dietrich, "International Sales Law, United Nations Convention on Contracts for the International Sale of Goods, Convention on the Limitation Period in the International Sale of Goods", Oceana Publications, 1992, disponível em http://www.cisg.law.pace.edu/cisg/biblio/enderlein.html\#art79].
} 
própria cumprir os requisitos do Artigo 79(1) e o terceiro envolvido também cumprir os mesmos requisitos, caso lhe fossem aplicáveis ${ }^{60}$.

A regra do Artigo 79(2) destina-se apenas àquelas situações nas quais o devedor de uma obrigação tenha delegado a um terceiro o cumprimento de todas ou parte de suas obrigações contratuais. Como as partes contratantes normalmente não terão o direito de delegar o cumprimento de suas obrigações a terceiros, esse dispositivo pressupõe a seguinte situação: o vendedor, depois de firmar um contrato de compra e venda e antes de inadimplir qualquer obrigação, delega a um terceiro independente o cumprimento de todas ou parte de suas obrigações com o comprador. Posteriormente, o vendedor se torna inadimplente e alega que o descumprimento contratual ocorreu em função da falha do terceiro independente ${ }^{61}$.

Seria o caso, por exemplo, de um vendedor de frutas tropicais contratado para entregar duas toneladas de laranja e uma tonelada de banana para o comprador em certa data. Após a conclusão do contrato, ocorrem fortes chuvas em sua plantação, que danificam as bananeiras e impedem que o vendedor cumpra com essa parte do contrato. Frente a essa situação, o vendedor contrata outro produtor de bananas e o instrui a entregar uma tonelada da fruta diretamente para o comprador, na data acordada. Ocorre que toda a carga desse produtor é roubada a caminho da entrega, e o contrato é parcialmente inadimplido. Nesse caso, de acordo com a CISG, para o vendedor ser exonerado da obrigação de pagar perdas e

\footnotetext{
${ }^{60}$ LOOKOFSKY, Joseph, “Article 79, Liability Exemptions for Failure to Perform; excerpt from The 1980 United Nations Convention on Contracts for the International Sale of Goods", disponível em http://www.cisg.law.pace.edu/cisg/text/secomm/secomm-79.html.

${ }^{61}$ LOOKOFSKY, Joseph, “Article 79, Liability Exemptions for Failure to Perform; excerpt from The 1980 United Nations Convention on Contracts for the International Sale of Goods", disponível em http://www.cisg.law.pace.edu/cisg/text/secomm/secomm-79.html.
} 
danos, ele terá que provar que ele e o produtor de bananas, cumulativamente, se adequam aos requisitos do Artigo 79(1).

No que diz respeito às partes envolvidas no cumprimento de um contrato, além de credor e devedor, os doutrinadores distinguem três grupos: (1) os empregados das partes; (2) aqueles que criam os prérequisitos necessários para o devedor conduzir seu negócio e cumprir com suas obrigações (aqui chamados de fornecedores); e (3) os terceiros independentes, descritos no parágrafo (2) do Artigo 79 (aqui chamados de subcontratados).

Determinar se o dispositivo aplicável é o 79(1) ou o 79(2) é relevante para aferir-se o ônus da prova: quando o segundo parágrafo do artigo é o dispositivo regente, o ônus da prova será maior, pois o inadimplente terá que provar que os requisitos do 79(1) foram satisfeitos por ele e pelo terceiro envolvido ${ }^{62}$. Está claro que as partes sempre são responsáveis por seus empregados, uma vez que claramente se encontram dentro de sua esfera de risco e, portanto, não há controvérsia quanto à aplicação do Artigo 79(1) para quebras contratuais provocadas por eles. No entanto, afirma a Opinião número 7 do Advisory Council que "[I]t is not self evident who are the "third persons" referred to in the second paragraph of Article 79 (...) ${ }^{\prime 63}$. A delimitação das diferenças entre os fornecedores e os

\footnotetext{
${ }^{62}$ CISG-AC Opinion No. 7, "Exemption of Liability for Damages under Article 79 of the CISG", Rapporteur: Professor Alejandro M. Garro, Columbia University School of Law, New York, N.Y., USA. Adotado pela CISG-AC na $11^{\mathrm{a}}$ reunião, em Wuhan, República Popular da China, em $12 \mathrm{de}$ Outubro de 2007 disponível em http://www.cisg.law.pace.edu/cisg/CISG-AC-op7.html.

${ }^{63}$ CISG-AC Opinion No. 7, "Exemption of Liability for Damages under Article 79 of the CISG", Rapporteur: Professor Alejandro M. Garro, Columbia University School of Law, New York, N.Y., USA. Adotado pela CISG-AC na $11^{a}$ reunião, em Wuhan, República Popular da China, em 12 de Outubro de 2007 disponível em http://www.cisg.law.pace.edu/cisg/CISG-AC-op7.html.

Nas palavras de Schwenzer, "It is not always easy to differentiate precisely between a person assisting in performance, for whose conduct the promisor is strictly liable as part of his personnel risk under Article 79(1), and an independent third person within the meaning of Article 79(2) (...)" [SCHELECHTRIEM, Peter e SCHWENZER, Ingeborg "Commentary on the UN Convention on the International Sale of Goods (CISG)”, $3^{\text {a }}$ edição, Oxford University Press, 2010, p. 1078].
} 
subcontratados apresenta-se mais sensível, uma vez que são figuras próximas e a caracterização de um subcontratado implica na duplicação do ônus da prova da parte inadimplente ${ }^{64}$.

Os doutrinadores entendem que os fornecedores são aqueles que, apesar de não serem incumbidos de cumprir o contrato diretamente com o credor, criam as condições necessárias para que o devedor o faça. São eles os agentes auxiliares, ou aqueles responsáveis por entregar ao devedor matérias primas e partes semimanufaturadas, cujo adimplemento é condição necessária para que o devedor cumpra com o contrato principal. Novamente, afirma a Opinião número 7 do Advisory Council que "[T]hese third-party suppliers or subcontractors, to whom the seller turns as a source for the supply of the goods, are not the type of "third persons" contemplated in Article 79(2)" ${ }^{65}$. Dessa forma, fica claro que quando o

64 ENDERLEIN, Fritz e MASKOW, Dietrich, "International Sales Law, United Nations Convention on Contracts for the International Sale of Goods, Convention on the Limitation Period in the International Sale of Goods", Oceana Publications, 1992, disponível em http://www.cisg.law.pace.edu/cisg/biblio/enderlein.html\#art79.

\footnotetext{
Nas palavras de Schwenzer, “Under Article 79(2), the promisor's burden of proof is twofold: he can only be exempted from liability if he proves, first, that the impediment was uncontrollable for him and, second, that the third person, if he were the promisor, would himself be exempted under Article 79(1). Since the requirements of Article 79(2) are cumulative, this provision, in the end, leads to stricter liability" [SCHELECHTRIEM, Peter e SCHWENZER, Ingeborg "Commentary on the UN Convention on the International Sale of Goods (CISG)", $3^{\mathrm{a}}$ edição, Oxford University Press, 2010, p. 1079].

${ }^{65}$ CISG-AC Opinion No. 7, "Exemption of Liability for Damages under Article 79 of the CISG", Rapporteur: Professor Alejandro M. Garro, Columbia University School of Law, New York, N.Y., USA. Adotado pela CISG-AC na $11^{a}$ reunião, em Wuhan, República Popular da China, em 12 de Outubro de 2007 disponível em http://www.cisg.law.pace.edu/cisg/CISG-AC-op7.html.

Nas palavras de Schwenzer, “(...) upstream suppliers do not fall under the scope of Article 79(2). They merely create the preconditions for the promisor's performance or assist in the preparation for performance; they are not entrusted with performance in whole or in part. They may supply the seller with raw materials or semi-manufactured parts necessary for the manufacture of the goods or, where the seller is only a dealer or a commission agent, even with the goods themselves. Impediments which were caused by the supplier are treated according to the general rule of Article 79(1). The promisor's liability for the supplier is part of his general risk that the goods will actually be procured. Consequently, the seller is, as a rule, not exempted if the supplier does not deliver at all or delivers defective goods, even when this was not foreseeable" [SCHELECHTRIEM, Peter e SCHWENZER, Ingeborg "Commentary on the UN Convention on the International Sale of Goods (CISG)”, $3^{\text {a }}$ edição, Oxford University Press, 2010, p. 1079].
} 
descumprimento contratual deve-se a uma falha dos fornecedores do devedor, o dispositivo aplicável será o Artigo $79(1)^{66}$.

Joseph Lookofsky, ao comentar o Caso Vine Wax, afirma que o Artigo 79 não altera a alocação de riscos da CISG, o vendedor deve garantir que o seu fornecedor entregue a ele bens sem defeitos, e a tempo de o vendedor cumprir com o contrato principal. Por essa razão, o comprador não precisa distinguir entre os casos nos quais o vendedor é o produtor do bem dos casos em que o vendedor obtém os bens no mercado. A simples falha do fornecedor não poderá ser alegada como impedimento ao cumprimento contratual, pois a atuação do fornecedor é garantida pelo vendedor $^{67}$.

Atribuir ao vendedor a responsabilidade pelas ações de seu fornecedor é consistente com a política de alocar os riscos de um inadimplemento na parte que está na melhor posição de evitar ou minimizar esses riscos ${ }^{68}$. O vendedor poderá ser exonerado de uma obrigação em

\footnotetext{
${ }^{66}$ Nesse sentido, ao analisar a aplicação do Artigo 79(2), a Corte de Apelação de Lugano (Appellate Court Lugano), ao julgar o Modular Wall Partitions Case, afirmou que: "The seller's employees and suppliers are not considered third parties according to the CISG, though they are subjects who, autonomously or as independent parties, fulfill a part or the whole of the contract" [Switzerland 29 October 2003 Appellate Court Lugano, Cantone del Ticino (Modular wall partitions case) http://cisgw3.law.pace.edu/cases/031029s1.html].
}

No mesmo sentido, afirma Schlechtriem, ao comentar o Caso Vine Wax, afirma que: "There is much to be said in favor of considering suppliers and their suppliers as third parties under Art. 79(2) CISG. This would practically eliminate an exemption for the seller in cases of nonconformity to the contract since the suppliers and their suppliers would not qualify for exemption as far as they produced the goods themselves.[16] The result of the decision of the German Federal Supreme Court (BGH) that the seller is liable for suppliers and (all of) their suppliers as though the seller had himself produced the goods (the defect thus comes from within his "sphere of control") could thus easily be arrived at" [Federal Supreme Court (Bundesgerichtshof), Civil Panel VII March 24, 1999, Index No. VIII ZR 121/98, Comentário por Peter Schlechtriem, Tradução por Todd Fox e Sonja Corterier, disponível em http://cisgw3.law.pace.edu/cases/990324g1.html].

${ }^{67}$ LOOKOFSKY, Joseph; Article 79, Liability Exemptions for Failure to Perform; excerpt from The 1980 United Nations Convention on Contracts for the International Sale of Goods, in: http://www.cisg.law.pace.edu/cisg/text/secomm/secomm-79.html.

${ }^{68}$ CISG-AC Opinion No. 7, "Exemption of Liability for Damages under Article 79 of the CISG", Rapporteur: Professor Alejandro M. Garro, Columbia University School of Law, New York, N.Y., 
casos extremos, como no caso em que o fornecedor é a única fonte disponível das mercadorias em questão, ou quando os fornecedores encontram-se indisponíveis em função de eventos extraordinários e imprevisíveis ${ }^{69}$. De qualquer forma, quando houver inadimplemento em função da falha de um fornecedor, o dispositivo aplicável será o Artigo 79(1), e só precisarão ser analisados os requisitos desse artigo em relação ao devedor da obrigação principal ${ }^{70}$.

Para que o Artigo 79(2) se aplique, é necessária a presença de terceiros independentes, que o devedor envolve na relação contratual para que cumpram certas obrigações diretamente ao credor. Os terceiros a que se refere o dispositivo são aqueles que não são meramente pessoas jurídicas distintas do devedor, mas também economicamente independentes do devedor, fora de sua estrutura organizacional, esfera de controle ou responsabilidade $^{71}$. O dispositivo pressupõe que a terceira pessoa foi chamada depois da conclusão do contrato principal, de forma a permitir o cumprimento daquele contrato em específico ${ }^{72}$. Ou seja, não se trata aqui de fornecedores genéricos, que regularmente atendem ao devedor e fazem

USA. Adotado pela CISG-AC na $11^{\mathrm{a}}$ reunião, em Wuhan, República Popular da China, em 12 de Outubro de 2007 disponível em http://www.cisg.law.pace.edu/cisg/CISG-AC-op7.html.

${ }^{69}$ SCHLECHTRIEM, Peter, “Commentary on Federal Supreme Court (Bundesgerichtshof), Civil Panel VII, in Review of the Convention on Contracts for the International Sale of Goods (CISG)", Kluwer Law International (2000-2001); Advisory Council Opinion n.7.

${ }^{70}$ Nesse sentido, também a Corte de Apelação de Hamburgo (Appellate Court of Hamburg), ao julgar o Iron Molybbdenum Case afirmou que: "The delivery by one's own supplier is a part of the general risk to acquire the goods, which is, according to the typical sense of the contract, borne by the Seller if the contract is not limited to a certain production or storage. The Seller is not exempted if its supplier has not delivered, even if the supplier's action was unforeseeable and a breach of contract. Such an impediment can be overcome by the Seller as long as there are replacement goods available on the market" [Germany 28 February 1997 Appellate Court Hamburg (Iron molybdenum case), disponível em http://cisgw3.law.pace.edu/cases/970228g1.html].

${ }^{71}$ CISG-AC Opinion No. 7, "Exemption of Liability for Damages under Article 79 of the CISG", Rapporteur: Professor Alejandro M. Garro, Columbia University School of Law, New York, N.Y., USA. Adotado pela CISG-AC na $11^{\mathrm{a}}$ reunião, em Wuhan, República Popular da China, em 12 de Outubro de 2007 disponível em http://www.cisg.law.pace.edu/cisg/CISG-AC-op7.html.

${ }^{72}$ SCHELECHTRIEM, Peter e SCHWENZER, Ingeborg "Commentary on the UN Convention on the International Sale of Goods (CISG)", $3^{\mathrm{a}}$ edição, Oxford University Press, 2010, p. 1078. 
parte de sua estrutura. O Artigo 79(2) destina-se a regular os casos em que terceiros independentes são chamados a atuar em função de uma compra e venda em particular.

O dispositivo em análise aumenta a responsabilidade do vendedor, já que a falha de um terceiro independente lhe será imputada como se fosse sua própria falha, seu próprio inadimplemento. A responsabilidade do vendedor não é incondicional, e pode ser mitigada quando ele não teve controle sobre a escolha do terceiro independente, quando esse terceiro é um monopolista, e em qualquer outro caso em que o vendedor seja capaz de provar que a falha do terceiro estava de fato fora de seu controle ${ }^{73}$.

Apesar de a maioria dos doutrinadores afirmar que o Artigo 79(2) torna a exoneração do vendedor mais difícil de ser alcançada, em função da duplicação do ônus da prova imposta pelo dispositivo, há que se relativizar tal afirmativa. ${ }^{74} \mathrm{O}$ parágrafo segundo do Artigo 79 destina-se a regular o inadimplemento causado por uma certa categoria de parceiros do vendedor. A forma de se analisar a responsabilidade do vendedor muda com a aplicação desse dispositivo, pois as circunstâncias do caso concreto também mudam quando há a participação de um terceiro independente. Afirmam Fritz Enderlein e Dietrich Maskow que "[A] differentiation of the rule aims

\footnotetext{
${ }^{73}$ CISG-AC Opinion No. 7, "Exemption of Liability for Damages under Article 79 of the CISG", Rapporteur: Professor Alejandro M. Garro, Columbia University School of Law, New York, N.Y., USA. Adotado pela CISG-AC na $11^{a}$ reunião, em Wuhan, República Popular da China, em 12 de Outubro de 2007 disponível em http://www.cisg.law.pace.edu/cisg/CISG-AC-op7.html.

${ }^{74}$ No sentido de que o Artigo 79(2) dificulta a exoneração do vendedor: CISG-AC Opinion No. 7, "Exemption of Liability for Damages under Article 79 of the CISG", Rapporteur: Professor Alejandro M. Garro, Columbia University School of Law, New York, N.Y., USA. Adotado pela CISG-AC na $11^{\text {a }}$ reunião, em Wuhan, República Popular da China, em 12 de Outubro de 2007 disponível em http://www.cisg.law.pace.edu/cisg/CISG-AC-op7.html.
}

SCHELECHTRIEM, Peter e SCHWENZER, Ingeborg "Commentary on the UN Convention on the International Sale of Goods (CISG)”, $3^{\mathrm{a}}$ edição, Oxford University Press, 2010, p. 1079.

LOOKOFSKY, Joseph, “ Article 79, Liability Exemptions for Failure to Perform; excerpt from The 1980 United Nations Convention on Contracts for the International Sale of Goods", disponível em http://www.cisg.law.pace.edu/cisg/text/secomm/secomm-79.html. 
toward finding proper solutions for different circumstances",75. Quando se trata de fornecedores, o vendedor jamais poderá alegar sua falha como um impedimento, por exemplo. Em relação a terceiros independentes, a mesma restrição não se aplica, eis que sua falha pode ser alegada como um impedimento, se o vendedor for capaz de provar que tal falha estava de fato fora de seu controle.

No entanto, apesar dos esforços doutrinários, a aplicação do Artigo 79 a casos em que há a participação de terceiros no cumprimento contratual não é pacífica. Ao se analisar a história legislativa do Artigo 79, percebe-se grande confusão entre os participantes ao tentarem determinar o escopo de aplicação dos parágrafos primeiro e segundo do Artigo 79. Alguns autores, como Joseph Lookofsky, falam em "chaotic discussions which preceded the rule's adoption in Vienna" ${ }^{, 76}$. Portanto, conclui-se que o parágrafo segundo do artigo deve ser interpretado de forma bastante restritiva, sendo aplicado somente nos casos em que de fato o terceiro independente cumpre com certas obrigações diretamente ao comprador ${ }^{77}$.

75 ENDERLEIN, Fritz e MASKOW, Dietrich, "International Sales Law, United Nations Convention on Contracts for the International Sale of Goods, Convention on the Limitation Period in the International Sale of Goods", Oceana Publications, 1992, disponível em http://www.cisg.law.pace.edu/cisg/biblio/enderlein.html\#art79.

${ }^{76}$ LOOKOFSKY, Joseph, “Article 79, Liability Exemptions for Failure to Perform; excerpt from The 1980 United Nations Convention on Contracts for the International Sale of Goods", disponível em http://www.cisg.law.pace.edu/cisg/text/secomm/secomm-79.html.

${ }^{77}$ CISG-AC Opinion No. 7, "Exemption of Liability for Damages under Article 79 of the CISG", Rapporteur: Professor Alejandro M. Garro, Columbia University School of Law, New York, N.Y., USA. Adotado pela CISG-AC na $11^{a}$ reunião, em Wuhan, República Popular da China, em 12 de Outubro de 2007 disponível em http://www.cisg.law.pace.edu/cisg/CISG-AC-op7.html.

Nesse sentido, Schlechtriem afirma que: “(...) Article 79(1) remains the controlling provision in cases where the third party's performance is a mere precondition for the fulfillment of the obligor's obligations, i.e., where a third party does not directly fulfill the obligor's duty to the oblige" [SCHLECHTRIEM, Peter, "Commentary on Federal Supreme Court (Bundesgerichtshof), Civil Panel VII, in Review of the Convention on Contracts for the International Sale of Goods (CISG) ’, Kluwer Law International (2000-2001)].

Nesse sentido também Flambouras afirma que: “It is suggested that the seller's suppliers should not be considered third persons for the purposes of CISG Article 79(2), since such persons simply create the preconditions or assist in the preparation for the performance of the promisor's obligation without, however, performing all or part of the actual contract." [FLAMBOURAS, 


\subsubsection{Impedimentos temporários - Artigo 79(3).}

Afirma o Artigo 79(3) que:

Artigo 79(3)

"A exclusão prevista neste artigo produzirá efeito enquanto durar o impedimento.",78

Impedimentos incontroláveis que temporariamente obstam o cumprimento contratual eximem o devedor de pagar perdas e danos pelo descumprimento do contrato. No entanto, quando o impedimento deixa de existir, o devedor tem a obrigação de cumprir com o contrato.

Esse dispositivo não afeta o direito do credor de resolver o contrato de acordo com o Artigo 49 da Convenção ("right to avoid the contract"), que pode surgir caso o tempo seja fator essencial ao contrato, de forma que $\mathrm{o}$ atraso em seu cumprimento caracterize um inadimplemento fundamental no sentido do Artigo 25 da CISG $^{79}$.

Dionysios, "The Doctrines of Impossibility of Performance and clausula rebus sic stantibus in the 1980 Vienna Convention on Contracts for the International Sale of Goods and the Principles of European Contract Law: A Comparative Analysis", disponível em: http://www.cisg.law.pace.edu/cisg/biblio/flambouras1.html].

78 Tradução de Eduardo Grebler e Gisely Radael, disponível em http://www.cisgbrasil.net/doc/egrebler2.pdf.

Texto do artigo em inglês:

Article 79(3)

"The exemption provided by this article has effect fot the period during which the impediment exists."

${ }^{79}$ SCHELECHTRIEM, Peter e SCHWENZER, Ingeborg "Commentary on the UN Convention on the International Sale of Goods (CISG)”, $3^{\mathrm{a}}$ edição, Oxford University Press, 2010, p. 1080. 


\title{
1.2. Notificação de Exoneração - Artigo 79(4).
}

A parte que alega uma exoneração de responsabilidade tem o dever de notificar a outra parte sobre o impedimento e suas consequências no cumprimento contratual. Estabelece o Artigo 79(4) que:

\begin{abstract}
Artigo 79(4):
"A parte que não executar as suas obrigações deve advertir a outra parte do impedimento e dos seus efeitos sobre sua capacidade de cumprir o contrato. Se a advertência não chegar ao destino em um prazo razoável, a partir do momento em que a parte que não executou as suas obrigações conheceu ou deveria conhecer o impedimento, esta é obrigada a reparar perdas e danos decorrentes da falta de recepção da comunicação. "
\end{abstract}

O dever positivado no Artigo 79(4) é uma expressão do dever geral de cooperação presente na CISG. A notificação deve permitir que a outra parte avalie se ela pode tomar medidas de forma a mitigar os danos causados pelo inadimplemento do devedor, ou se tal descumprimento constitui um inadimplemento fundamental, de forma a ensejar a resolução do contrato ${ }^{81}$.

A notificação deve descrever a natureza, gravidade e duração do impedimento em detalhes. Ela deve ser feita em um período de tempo razoável a contar da data em que o devedor soube ou deveria saber do impedimento, e não está sujeita a nenhuma formalidade. Estabelece o

\footnotetext{
${ }^{80}$ Tradução de Iacyr de Aguilar Vieira, disponível em http://www.cisg-brasil.net/doc/iacyr1.html.

Texto do artigo em inglês:

Article 79(4)

"The party who fails to perform must give notice to the other party of the impediment and its effect on his ability to perform. If the notice is not received by the other party within a reasonable time after the party who fails to perform knew or ought to have known of the impediment, he is liable for damages resulting from such non-receipt.'

${ }^{81}$ SCHELECHTRIEM, Peter e SCHWENZER, Ingeborg "Commentary on the UN Convention on the International Sale of Goods (CISG)”, $3^{\mathrm{a}}$ edição, Oxford University Press, 2010, p. 1081.
} 
dispositivo em questão que o risco de a notificação chegar ao credor é do devedor. Portanto, caso o credor não seja adequadamente notificado, o devedor será responsável pelos danos provenientes da quebra do dever de notificar. Vale notar que essa é a única consequência da falta de notificação, posto que ela não impede o devedor de ser exonerado da obrigação de pagar a indenização por perdas e danos resultante do inadimplemento da obrigação principal ${ }^{82}$.

\subsection{Efeitos da aplicação do Artigo 79.}

O efeito da aplicação do Artigo 79 ao devedor restringe-se à exoneração da obrigação de pagar a indenização por perdas e danos estabelecida na CISG em função do descumprimento contratual. É o que estabelece o Artigo 79(5) da Convenção:
Artigo 79(5):
"As disposições do presente artigo não impedem as partes de exercerem quaisquer dos seus direitos, salvo o de obter indenização por perdas e danos, nos termos da presente Convenção. "83

A exoneração diz respeito apenas à obrigação contratual descumprida, de maneira que não afeta a existência do contrato e de outras obrigações contratuais. Além disso, a aplicação do artigo também não altera o fato de que ocorreu um inadimplemento contratual ${ }^{84}$.

\footnotetext{
${ }^{82}$ SCHELECHTRIEM, Peter e SCHWENZER, Ingeborg "Commentary on the UN Convention on the International Sale of Goods (CISG)", $3^{\mathrm{a}}$ edição, Oxford University Press, 2010, p. 1081.

${ }^{83}$ Tradução de Iacyr de Aguilar Vieira, disponível em http://www.cisg-brasil.net/doc/iacyr1.html.

Texto do artigo em inglês:

Article 79(5)

"Nothing in this article prevents either party from exercising any right other than to claim damages under this Convention."

${ }^{84}$ SCHELECHTRIEM, Peter e SCHWENZER, Ingeborg "Commentary on the UN Convention on

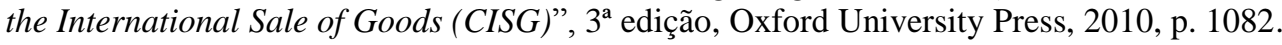


Caso o devedor seja exonerado de cumprir com apenas parte de suas obrigações, ele estará isento da indenização por perdas e danos em relação unicamente àquela parte. Imaginemos, por exemplo, um contrato de compra e venda de 100 toneladas de laranja entre um vendedor americano e um comprador norueguês. Ocorre um incêndio e parte do estoque do vendedor pega fogo, queimando $40 \%$ das mercadorias que ele iria entregar ao comprador. Nesse caso, ainda que o vendedor seja exonerado quanto à parte da obrigação contratual, o comprador poderá exigir a entrega do $60 \%$ restante das laranjas, uma vez que o direito de exigir o cumprimento específico do contrato não é excluído pela aplicação do artigo.

Em casos como esse, se o vendedor não entregar o restante da mercadoria, o credor poderá rescindir o contrato e reclamar a indenização por perdas e danos decorrente de tal descumprimento parcial, de acordo com o Artigo 64 (1) (a) ou (b) da CISG $^{85}$. É de se notar que, caso o impedimento afete a totalidade das mercadorias, o comprador ainda reterá o direito de exigir o cumprimento específico das obrigações em um momento posterior, quando o impedimento cessar ${ }^{86}$. No entanto, caso o cumprimento

${ }^{85}$ HONNOLD, John, "Uniform Law for International Sales Under the 1980 United Nations Convention"; $\quad 3^{\mathrm{a}} \quad$ edição (1999), $\quad$ disponível em http://www.cisg.law.pace.edu/cisg/biblio/honnold.html.

Artigo 64:

"(1) The seller may declare the contract avoided:

(a) if the failure by the buyer to perform any of his obligations under the contract or this Convention amounts to a fundamental breach of contract; or

(b) if the buyer does not, within the additional period of time fixed by the seller in accordance with paragraph (1) of article 63, perform his obligation to pay the price or take delivery of the goods, or if he declares that he will not do so within the period so fixed.

(...)"

${ }^{86}$ Quanto aos efeitos da aplicação do Artigo 79 a um caso de onerosidade excessiva, aceito por alguns doutrinadores, comenta Schwenzer que: "Other impediments, as in particular when performance is rendered more onerous eg in cases of subjective impossibility, do not lead to the loss of the claim for specific performance. Allowing the claim for specific performance with no restrictions or even the imposition of liquidated damages, however, would undermine the exemption of the promisor intended by Article 79. Even if the claim for specific performance is assumed to subsist in such cases, it will, in any case, not be enforceable as long as the impediment exists. In case of hardship it is suggested to resort to Article 6.2.3(1) PICC, thus giving the aggrieved party the right to renegotiate the contract" [SCHELECHTRIEM, Peter $\mathrm{e}$ SCHWENZER, Ingeborg "Commentary on the UN Convention on the International Sale of Goods (CISG)", 3rd. ed., Oxford University Press, 2010, p. 1084]. 
contratual se torne impossível, quando há, por exemplo, a destruição total das mercadorias compradas, claramente não haverá direito a pleitear de cumprimento específico ${ }^{87}$.

Além disso, quando o impedimento afeta a totalidade das obrigações em um contrato e o devedor é exonerado através da aplicação do Artigo 79, o credor retém o direito de rescindir o contrato caso o atraso ou a falta de cumprimento da obrigação atingida pelo impedimento constitua um inadimplemento fundamental nos termos do Artigo 25 da CISG, isto é, caso o credor objetivamente perca o interesse no contrato ${ }^{88}$.

Consideremos dois casos: (1) um vendedor entrega os bens ao comprador, mas restrições cambiais impedem o comprador de pagar o acordado; e (2) um comprador de sapatos efetua pagamento adiantado pela mercadoria comprada, mas barreiras à exportação impostas pelo país do vendedor o impedem de entregar os bens. Nesses casos, a parte que é impedida de adimplir o contrato será exonerada da obrigação de pagar perdas e danos. Porém, a outra parte terá o direito de rescindir o contrato e ser restituída dos bens ou do dinheiro que transferiu à parte exonerada, de forma a retornar ao status quo ante à assinatura do contrato ${ }^{89}$.

Pela redação do Artigo 79, percebe-se que não está claro se a exoneração se estende às indenizações contratuais, tais como os liquidated

\footnotetext{
${ }^{87}$ SCHELECHTRIEM, Peter e SCHWENZER, Ingeborg "Commentary on the UN Convention on the International Sale of Goods (CISG)", $3^{\mathrm{a}}$ edição, Oxford University Press, 2010, p. 1084.

${ }^{88}$ Artigo 25:

"A breach of contract committed by one of the parties is fundamental if it results in such detriment to the other party as substantially to deprive him of what he is entitled to expect under the contract, unless the party in breach did not foresee and a reasonable person of the same kind in the same circumstances would not have foreseen such a result."

${ }^{89}$ HONNOLD, John, "Uniform Law for International Sales Under the 1980 United Nations Convention"; $\quad 3^{\mathrm{a}} \quad$ edição $\quad$ (1999), $\quad$ disponível http://www.cisg.law.pace.edu/cisg/biblio/honnold.html.
} 
damages. A consequência da aplicação do Artigo 79 a esses ajustes contratuais deve ser analisada, primeiramente, à luz do próprio contrato em cada caso concreto. No entanto, é importante reparar que de acordo com o Artigo 4(a) da Convenção, a validade dos contratos deverá ser aferida de acordo com a lei nacional aplicável ${ }^{90}$. Schwenzer sugere que, em caso de dúvida, a exoneração deverá igualmente ser aplicada às indenizações contratuais $^{91}$.

Além disso, é importante ressaltar que o artigo em questão não exclui o direito do credor de cobrar juros do devedor. Afirma Schwenzer que o direito de cobrar indenização é distinto do direito de cobrar juros ${ }^{92}$. Por isso, o dever de pagar juros subsiste caso o devedor de uma obrigação monetária seja exonerado de sua obrigação de pagar indenização por perdas e danos em função de algum impedimento.

Portanto, entende-se que a aplicação do Artigo 79 não exclui nenhum outro direito além daquele de exigir indenização por perdas e danos ${ }^{93}$. O

\footnotetext{
90 Artigo 4:

"This Convention governs only the formation of the contract of sale and the rights and obligations of the seller and the buyer arising from such a contract. In particular, except as otherwise expressly provided in this Convention, it is not concerned with:

(a) the validity of the contract or of any of its provisions or of any usage;

(b) the effect which the contract may have on the property in the goods sold."

${ }^{91}$ SCHELECHTRIEM, Peter e SCHWENZER, Ingeborg "Commentary on the UN Convention on the International Sale of Goods (CISG)", $3^{\mathrm{a}}$ edição, Oxford University Press, 2010, p. 1083.

${ }^{92}$ SCHELECHTRIEM, Peter e SCHWENZER, Ingeborg "Commentary on the UN Convention on the International Sale of Goods (CISG)”, $3^{\text {a }}$ edição, Oxford University Press, 2010, p. 1085.

${ }^{93}$ SCHELECHTRIEM, Peter e SCHWENZER, Ingeborg "Commentary on the UN Convention on the International Sale of Goods (CISG)”, $3^{\mathrm{a}}$ edição, Oxford University Press, 2010, p. 1085.

Nesse sentido, afirma Schlechtriem, ao comentar o Caso Vine Wax, que: “According to Art. 79(5) CISG other remedies still remain viable when an obligor qualifies for an exemption. For the seller's liability due to non-conforming goods that means that the buyer still has the right to a price reduction under Art. 50 CISG, to demand cure so long as the necessary prerequisites for cure or delivery of substitute goods are met, and in certain exceptional cases to declare the contract avoided." [Federal Supreme Court (Bundesgerichtshof), Civil Panel VII March 24, 1999, Index No. VIII ZR 121/98, Comentário por Peter Schlechtriem, Tradução por Todd Fox e Sonja Corterier, disponível em http://cisgw3.law.pace.edu/cases/990324g1.html].
} 
credor retém todos os outros direitos garantidos pela CISG em função da falta de cumprimento ou cumprimento defeituoso do contrato, tais como rescisão ou diminuição no preço das mercadorias ${ }^{94}$.

\begin{abstract}
Nesse sentido, também, o Digest da UNICTRAL sobre a CISG: "Paragraph (5) makes it clear that article 79 has only a limited effect on the remedies available to a party aggrieved by a failure of performance for which the non-performing party enjoys an exemption. Specifically, article 79 (5) declares that an exemption precludes only the aggrieved party's right to claim damages, and not any other rights of either party under the Convention." [UNCITRAL Digest of Case Law on the United Nations Convention on Contracts for the International Sale of Goods, p.388, 2012 Edition, disponível em http://www.uncitral.org/pdf/english/clout/CISG-digest-2012-e.pdf].
\end{abstract}

${ }^{94}$ Sobre os direitos conferidos pela CISG à parte lesada em caso de inadimplemento contratual (remedies):

BUTLER, Allison E., "A Practical Guide to the CISG: Negotiations Through Litigation” Aspen Publishers (2007 Supplements), Capítulos 6 e 7, disponível em http://cisgw3.law.pace.edu/cisg/biblio/butler6.html;

CHENGWEI, Liu, "Remedies for Non-performance:Perspectives from CISG, UNIDROIT Principles \& PECL", disponível em http://www.cisg.law.pace.edu/cisg/biblio/chengwei.html;

KATZ, Avery W., "Remedies for breach of contract under the CISG", disponível em http://www.columbia.edu/ ak472/papers/Katz,\%2025\%20Int\%20Rev\%20L\%20Econ\%20378\%20 (2005)\%20(Remedies\%20for\%20Breach\%20of\%20Contract\%20Under\%20the\%20CISG).pdf;

MAGNUS, Ulrich, Hamburg, "The Remedy Of Avoidance Of Contract Under Cisg-General Remarks And Special Cases", disponível em: http://www.uncitral.org/pdf/english/CISG25/Magnus.pdf;

SHIN, Chang-Sop, "Declaration Of Price Reduction Under The Cisg Article 50 Price Reduction Remedy”, disponível em: http://www.uncitral.org/pdf/english/CISG25/Shin.pdf;

CISG-AC Opinion no 5, "The buyer's right to avoid the contract in case of non-conforming goods or documents" 7 May 2005, Badenweiler (Germany). Rapporteur: Professor Dr. Ingeborg Schwenzer, LL.M., Professor of Private Law, University of Basel. Adotado pela CISG-AC na $9^{\mathrm{a}}$ reunião feita na Filadélfia, com unanimidade, disponível em: http://www.cisg.law.pace.edu/cisg/CISG-AC-op5.html;

EISELEN, Siegfried, "A Comparison of the Remedies for Breach of Contract under the CISG and South African Law”, disponível em: http://www.cisg.law.pace.edu/cisg/biblio/eiselen2.html;

FERRARI, Franco, “The Interaction between the United Nations Conventions on Contracts for the International Sale of Goods and Domestic Remedies", disponível em http://www.cisg.law.pace.edu/cisg/biblio/ferrari16.html;

FLECHTNER, Harry M., "Remedies Under the New International Sales Convention: The Perspective from Article 2 of the U.C.C.", disponível em http://www.cisg.law.pace.edu/cisg/biblio/flecht.html. 


\subsection{Análise do caso hipotético apresentado à luz do Artigo $\mathbf{7 9}$ da Convenção.}

Para finalizar as considerações sobre o Artigo 79 da CISG, analisaremos o caso hipotético apresentado. $\mathrm{O}$ caso envolve três empresas: o comprador, o vendedor e uma terceira empresa, que fornece unidades de processamento de alta tecnologia para o vendedor. O comprador, que chamamos de Elite, pretende adquirir um aparato para conferências de alta tecnologia (sistema de controle máster) junto ao vendedor, para instalar em seu novo iate. O vendedor, por sua vez, compra de um fornecedor unidades de processamento, que utiliza para fabricar o sistema de controle desejado. Ocorre um incêndio na fábrica do fornecedor, que destrói a maior parte de seu estoque e ocasiona um atraso na entrega das unidades de processamento. Tal atraso na cadeia de produção causou perdas ao comprador, vez que impossibilitou a realização de um evento importante no novíssimo iate.

Inicialmente, teremos que analisar se a presença do fornecedor de unidades de processamento no contexto da compra e venda enseja a aplicação do Artigo 79(1) ou 79(2). Como já foi dito, o Artigo 79(2) destina-se a regular apenas aqueles casos nos quais o devedor delega a um terceiro parte de suas obrigações, de forma que o terceiro terá relação direta com o comprador. No caso apresentado, o fornecedor de unidades de processamento tinha relação exclusivamente com o vendedor, e apenas criou as condições necessárias para que o mesmo fosse capaz de fabricar o sistema de controle e cumprir com o contrato principal. Dessa forma, o dispositivo aplicável ao caso hipotético apresentado é o 79(1). Dito isso, passaremos a analisar os requisitos do Artigo 79(1).

O primeiro requisito do Artigo 79(1) exige, para que a parte inadimplente seja exonerada, a ocorrência de um impedimento fora de sua 
esfera de controle. Vimos que o vendedor deve garantir que o seu fornecedor lhe entregue bens sem defeitos e a tempo de garantir o cumprimento do contrato principal. Por isso, a falha do fornecedor não poderá ser alegada como impedimento. No entanto, se considerarmos que as medidas preventivas foram corretamente tomadas, o incêndio que ocorreu na fábrica do fornecedor é um evento imprevisível e extraordinário, que de fato impede o cumprimento da obrigação e pode ser caracterizado como um impedimento nos termos do preceito.

O segundo requisito, o requisito da previsibilidade, também é atingido pelo vendedor. Apesar de incêndios ocorrerem periodicamente, em fábricas de todos os tipos, não se trata de um evento conectado a um nicho de mercado específico. Na construção de hidrelétricas, por exemplo, o período de chuvas fortes é um acontecimento natural que precisa ser previsto no momento da conclusão do contrato, pois geralmente interfere em seu cumprimento. Incêndios não são eventos que geralmente interferem na fabricação de produtos, e por isso não são razoavelmente previsíveis.

$\mathrm{O}$ terceiro requisito do artigo, aquele que exige que a parte inadimplente tente evitar o impedimento ou suas consequências, é o mais difícil de ser cumprido. Como visto, o devedor tem a obrigação de tentar evitar as consequências nefastas de um impedimento até mesmo quando seus esforços resultarem em grande aumento de custos ou em prejuízo decorrente da transação. No caso apresentado, quando o vendedor recebeu a notificação de seu fornecedor a respeito do incêndio, limitou-se a informar ao comprador que não seria possível cumprir o contrato dentro do período de tempo acordado. Para se adequar ao Artigo 79, o vendedor teria que exaurir as opções disponíveis no mercado para evitar o atraso na entrega do sistema de controles. Uma opção plausível seria tentar comprar as unidades de processamento não afetadas pelo incêndio por preço superior ao originalmente estabelecido. Além disso, poderia o vendedor comprar outro 
sistema de controles no mercado e, dessa forma, entregar um bem substituto que satisfizesse o contrato de forma semelhante.

Como o vendedor nada fez frente à situação do incêndio, um dos requisitos do Artigo 79(1) não foi cumprido e, por isso, o vendedor não será exonerado de sua obrigação de pagar perdas e danos em função dos prejuízos causados ao comprador pelo atraso na entrega do sistema de controle. O Artigo 79 impõe requisitos que devem ser satisfeitos de forma cumulativa por aquele que pretende ser exonerado da obrigação de pagar indenização por descumprimento contratual. É por essa razão que, quando se aplica a CISG, a exoneração de responsabilidade é muito difícil de ser atingida pela parte inadimplente. 


\section{CAPÍTULO SEGUNDO}

\section{A Exclusão da Responsabilidade Civil Contratual em Virtude de Caso Fortuito ou de Força Maior no Código Civil Brasileiro}

Define-se a responsabilidade civil como o dever de indenizar o dano em função do descumprimento dos contratos ou das normas de direito positivo. $\mathrm{O}$ autor apresenta duas classificações acerca da responsabilidade civil: responsabilidade contratual (Código Civil, Artigos 389 a 416) e responsabilidade extracontratual (Código Civil, Artigos 186 a 188); e, sob a ótica da intenção do agente, responsabilidade objetiva e responsabilidade subjetiva. Apesar de admitir a responsabilidade objetiva em casos específicos, o Código Civil adotou, como regra geral, a responsabilidade subjetiva, baseada na prova de culpa do agente ${ }^{95}$. Afirma Rui Stoco que "[O] Direito Civil brasileiro estabelece que o princípio geral da responsabilidade civil, em direito privado, repousa na culpa"96. No presente capítulo iremos estudar a exclusão da responsabilidade civil contratual e, portanto, subjetiva ${ }^{97}$, em função de caso fortuito ou força maior, no Direito Civil Brasileiro.

São condições de existência da responsabilidade civil subjetiva, a ação ou omissão do agente, o dano, o nexo de causalidade e a culpa. Para que se configure a responsabilidade civil, é necessário que haja uma ação

\footnotetext{
95 SCAVONE JUNIOR, Luiz Antonio, “Causas e Cláusulas de Exclusão de Responsabilidade Civil"; in Revista de Direito Privado, n.8, outubro-dezembro de 2001, Editora Revista dos Tribunais, coordenação de Nelson Nery Junior e Rosa Maria de Andrade Nery.

96 STOCO, Rui, "Tratado de Responsabilidade Civil", 7ª edição, Editora Revista dos Tribunais, 2007, p. 158.

${ }^{97}$ Código Civil, Artigo 392: "Nos contratos benéficos, responde por simples culpa o contratante, a quem o contrato aproveite, e por dolo aquele a quem não favoreça. Nos contratos onerosos, responde cada uma das partes por culpa, salvo as exceções previstas em lei" (grifo nosso).
} 
ou omissão culposa do agente, e que dela resulte um dano ${ }^{98}$. A doutrina afirma que "o termo dano, em sentido amplo, vem a ser a lesão de qualquer bem jurídico, e aí se inclui o dano moral. Mas, em sentido estrito, dano é, para nós, a lesão do patrimônio; e patrimônio é o conjunto de relações jurídicas de uma pessoa, apreciáveis em dinheiro" "99. Claro é que sem dano, não há responsabilidade.

A culpa é o único elemento estrutural da responsabilidade civil que pode ser dispensado por lei, em se tratando de responsabilidade objetiva. No âmbito da responsabilidade subjetiva, a culpa é elemento central. Quando não demonstrada, o ressarcimento dos danos restará impossibilitado. A culpa lato sensu abrange a ação ou omissão, dolosa ou culposa. Dessa forma, quando o dano sobrevém involuntariamente, em função de negligência, imprudência ou imperícia, trata-se de culpa. No entanto, quando o ato é proposital, quando o dano é perseguido pelo agente, trata-se de dolo ${ }^{100}$.

Por fim, além da culpa, para que haja responsabilidade civil, é imprescindível a existência de um nexo de causalidade entre o dano sofrido pela vítima e a ação ou omissão do agente. Segundo Silvio Rodrigues, se a vítima sofrer um dano, mas não restar provado que tal dano resultou de ação ou omissão do réu, o pedido de indenização formulado deverá ser julgado improcedente ${ }^{101}$.

\footnotetext{
${ }^{98}$ SCAVONE JUNIOR, Luiz Antonio, "Causas e Cláusulas de Exclusão de Responsabilidade Civil"; in Revista de Direito Privado, n.8, outubro-dezembro de 2001, Editora Revista dos Tribunais, coordenação de Nelson Nery Junior e Rosa Maria de Andrade Nery.
}

99 ALVIM, Agostinho Neves de Arruda, "Da Inexecução de suas Obrigações e suas Consequências", $4^{\mathrm{a}}$ edição, 1972, Saraiva, p. 172.

100 Apud SCAVONE JUNIOR, Luiz Antonio, "Causas e Cláusulas de Exclusão de Responsabilidade Civil"; in Revista de Direito Privado, n.8, outubro-dezembro de 2001, Editora Revista dos Tribunais, coordenação de Nelson Nery Junior e Rosa Maria de Andrade Nery.

${ }^{101}$ SCAVONE JUNIOR, Luiz Antonio, "Causas e Cláusulas de Exclusão de Responsabilidade Civil"; in Revista de Direito Privado, n.8, outubro-dezembro de 2001, Editora Revista dos Tribunais, coordenação de Nelson Nery Junior e Rosa Maria de Andrade Nery, citando Silvio 
Após breve análise dos elementos constitutivos da responsabilidade civil, passaremos a estudar o caso fortuito e a força maior, causas excludentes de responsabilidade civil por ausência de culpa ou de nexo causal $^{102}$.

\title{
2.1. Caso fortuito e força maior.
}

\author{
Afirma o Artigo 393 do Código Civil Brasileiro que: \\ "Art. 393. O devedor não responde pelos prejuízos resultantes \\ de caso fortuito ou força maior, se expressamente não se \\ houver por eles responsabilizado." \\ "Parágrafo único. O caso fortuito ou de força maior verifica-se \\ no fato necessário, cujos efeitos não era possível evitar ou \\ impedir."
}

Rodrigues, “Direito Civil”, São Paulo, Editora Saraiva, 1989, vol. 4, “Responsabilidade Civil”, p. 18.

${ }^{102}$ Há autores que afirmam que o caso fortuito e a força maior excluem a responsabilidade civil em função da exclusão do nexo causal, outros afirmam que ocorre o mesmo efeito, porém em função da exclusão do elemento culpa. Aguiar Dias, por exemplo, afirma que "(...) o que anima as causas de isenção no seu papel de dirimentes é, em última análise, a supressão da relação de causalidade. Desaparecido o nexo causal, não é mais possível falar em obrigação de reparar" [DIAS, Aguiar, "Da Responsabilidade Civil", 6ª edição, Editora Forense, volume 1, pp. 362 e 363].

Da mesma forma, afirma Tiago Moraes Gonçalves que "[E]ntendia-se, tradicionalmente, que o fortuito era excludente da própria culpa. Hoje, até mesmo em razão da crescente "objetivação" da responsabilidade civil, já tratada anteriormente, a doutrina tem justificado a exclusão de responsabilidade pelo fortuito em razão do mesmo quebrar o nexo causal, por ser causa estranha à conduta do agente" [GONÇALVES, Tiago Moraes, "O Caso Fortuito e a Força Maior Frente à Responsabilização Objetiva pelo Risco da Atividade na Sociedade Contemporânea", in Revista de Direito Privado, volume 47, jul-set./2011].

Em sentido contrário, afirma Luiz Antonio Scavone Junior que: “Ousamos discordar da posição que defende a inexistência do liame de causalidade na exata medida em que é evidente a sua manutenção, restando, apenas, afastada a culpa, assim como na responsabilidade contratual. Aliás, essa é a lição dos Profs. Nery: 'o caso fortuito e o motivo de força maior excluem a culpa do agente, que é irrelevante para fixação do dever de indenizar no Código de Defesa do Consumidor" [SCAVONE JUNIOR, Luiz Antonio, "Causas e Cláusulas de Exclusão de Responsabilidade Civil"; in Revista de Direito Privado, n.8, outubro-dezembro de 2001, Editora Revista dos Tribunais, coordenação de Nelson Nery Junior e Rosa Maria de Andrade Nery]. 
No Direito Civil Brasileiro, via de regra, a responsabilidade do devedor exclui-se quando os prejuízos sofridos pelo credor se devam a caso fortuito ou de força maior ${ }^{103}$. Há intensos debates doutrinários acerca da conceituação desses termos, e, assim, diversas doutrinas surgiram com a intenção de diferenciá-los.

Rui Stoco, ao abordar o tema, afirma que "caso fortuito é o acontecimento natural, derivado de força da natureza ou o fato das coisas, como o raio, a inundação (...). Na força maior há um elemento humano, a ação das autoridades (factum principis), como ainda a revolução, o furto ou roubo, o assalto ou, noutro gênero, a desapropriação" ${ }^{\text {104 }}$. Carlos Alberto Dabus Maluf, por sua vez, defende critério diverso ao afirmar que caso fortuito é impedimento relacionado à pessoa do devedor ou à sua empresa, enquanto a força maior é acontecimento externo ${ }^{105}$. Já Orlando Gomes entende que caso fortuito se caracteriza pela imprevisibilidade do acontecimento, e força maior por sua irresistibilidade ${ }^{106}$.

Segundo Carvalho Santos, existem sete correntes distintas sobre o conceito e a diferenciação entre caso fortuito e força maior. A primeira, afirma que o fortuito é fundado na imprevisibilidade e a força maior na irresistibilidade. A segunda, que força maior é um acidente da natureza

\footnotetext{
${ }^{103}$ TEPEDINO, Gustavo, BARBOZA, Heloisa Helena, BODIN DE MORAES, Maria Celina, "Código Civil Interpretado conforme a Constituição da República", vol. 1, editora Renovar, $2^{\mathrm{a}}$ edição, 2007, p. 709.

${ }^{104}$ STOCO, Rui, "Tratado de Responsabilidade Civil", $7^{\mathrm{a}}$ edição, Editora Revista dos Tribunais, 2007, p. 181.

105 "A distinção que modernamente a doutrina vem estabelecendo, aquela que tem efeitos práticos e que já vai se introduzindo em algumas leis, é a que vê no caso fortuito um impedimento relacionado com a pessoa do devedor ou com a sua empresa, enquanto que a força maior é um acontecimento externo. Tal distinção permite estabelecer uma diversidade de tratamento para o devedor, consoante o fundamento de sua responsabilidade." [MALUF, Carlos Alberto Dabus, "Caso Fortuito e Força Maior Excludentes de Culpabilidade", Revista dos Tribunais, vol. 502, agosto de 1977].

${ }^{106}$ GOMES, Orlando, "Obrigações", $17^{\mathrm{a}}$ edição, atualizada por Edvaldo Brito, editora Forense, 2008, p. 180 .
} 
(inundação, terremoto), enquanto o fortuito é o fato do homem (guerra, violência). A terceira corrente não distingue os conceitos, mas entende que devem ser usados para designar os dois aspectos do mesmo fato, de forma que o fortuito se referiria à origem externa, e a força maior ao caráter invencível. A quarta corrente afirma que a força maior é um acontecimento estranho ao devedor, que não depende de investigação para exonerá-lo, enquanto que o fortuito exigiria a prova de que o devedor adotou a diligência necessária. Já a quinta corrente entende que apenas um requisito deve ser levado em consideração para a distinção entre os conceitos - a exterioridade. $\mathrm{O}$ fortuito teria seu ponto de partida no círculo interno do devedor, enquanto a força maior seria um fato exterior. A sexta corrente ensina que a distinção entre os conceitos seria importante se força maior fosse considerada para a exclusão da responsabilidade do devedor, e o fortuito como susceptível de reparação. Por fim, a sétima corrente defende que caso fortuito seria a impossibilidade relativa, e a força maior a impossibilidade absoluta ${ }^{107}$.

Apesar do esforço doutrinário empregado em distinguir as figuras, "[F]ato é que, se existe distinção, ela é inteiramente indiferente ao direito, já que as consequências coincidem. Tanto o caso fortuito quanto o de força maior desincumbem o devedor de responder pelas perdas e danos a que sua inexecução der causa" ${ }^{108}$. A maioria dos autores hoje afirma que a distinção entre os conceitos perde sua relevância, uma vez que é igual o efeito atribuído pelo Código Civil ${ }^{109}$.

107 BARBOSA DA SILVA, Joaquim Marcelo, “As Cláusulas Excludentes e Limitadoras da Responsabilidade Contratual. Caso Fortuito e Força Maior"; Revista de Direito Privado, n. 6, abril - junho de 2001. O autor cita J.M Carvalho dos Santos, "Código Civil Brasileiro Interpretado", vol. 14, pp. 231-237.

108 TEPEDINO, Gustavo, BARBOZA, Heloisa Helena, BODIN DE MORAES, Maria Celina, "Código Civil Interpretado conforme a Constituição da República", vol. 1, editora Renovar, $2^{\mathrm{a}}$ edição, 2007, p. 709.

109 GOMES, Orlando, “Obrigações”, 17ª edição, atualizada por Edvaldo Brito, editora Forense, 2008, p.180; 
Uma vez estabelecida a identidade entre caso fortuito e de força maior, cabe atentar aos conceitos sugeridos pela doutrina, em relação aos quais tão pouco há consenso. Orlando Gomes afirma que há duas teorias que se contrapõem na conceituação de fortuito e força maior: a teoria objetiva ou positiva e a teoria subjetiva ou negativa. De acordo com a teoria objetiva, o caso fortuito caracteriza-se pela imprevisibilidade ou irresistibilidade do evento que impede o cumprimento da obrigação. Portanto, o caso fortuito ou a força maior definem-se pela natureza do acontecimento.

Dentre os defensores da teoria objetiva, não há acordo quanto à qualidade do evento que impede o cumprimento da obrigação. Alguns afirmam que o evento deve ser, necessariamente, imprevisível. Outros entendem que pouco importa que o evento possa ser previsto, mas seus efeitos devem ser irresistíveis ou inevitáveis. A terceira corrente julga necessária a conjunção de ambos os requisitos. Dessa forma, defende que o evento deve ser irresistível e imprevisível.

Orlando Gomes observa que a teoria objetiva tem sido criticada por não atender ao fim perseguido pelo Direito em relação à ideia de caso fortuito. Afirma o autor que o evento fortuito não possui características intrínsecas e objetivas, reconhecíveis e absolutas. Na verdade, um

WALD, Arnoldo, "Direito Civil - Direito das Obrigações e Teoria Geral dos Contratos", volume 2, $18^{\mathrm{a}}$ edição, editora Saraiva, p. 153.

BARBOSA DA SILVA, Joaquim Marcelo, "As Cláusulas Excludentes e Limitadoras da Responsabilidade Contratual. Caso Fortuito e Força Maior"; Revista de Direito Privado, n. 6, abril - junho de 2001 .

STOCO, Rui, "Tratado de Responsabilidade Civil", 7a edição, Editora Revista dos Tribunais, 2007, p. 181.

LUCCO, Alexandre Luiz, "Caso Fortuito e Força Maior como Excludentes de Responsabilidade?", Revista Brasileira de Direito Civil Constitucional e Relações de Consumo, vol. 10, ano 3 - abril/junho 2011. 
acontecimento pode ser considerado fortuito em uma relação jurídica e não ser considerado da mesma forma em outra. Portanto, só é possível determinar se um evento constitui um fortuito capaz de exonerar o devedor subjetivamente, à luz da ideia de inimputabilidade. Caso o fortuito ou a força maior sejam considerados objetivamente, somente acontecimentos naturais extraordinários, ou fatos externos, seriam suficientes para exonerar o devedor de uma obrigação. Por essa razão, sugere o autor que a teoria subjetiva seria mais adequada para conceituar o fortuito e a força maior.

Segundo a teoria subjetiva, o fortuito ou a força maior devem ser conceituados pela ausência de culpa, quaisquer que sejam as características do acontecimento. Afirma Orlando Gomes que "[I]nteressa ao Direito determinar os casos em que o devedor responde pela inexecução. A regra geral, claramente intuitiva, firma-se no sentido de que deve indenizar os prejuízos decorrentes do inadimplemento sempre que resultem de culpa sua" ${ }^{110}$. Segundo ele, somente o devedor cuja inexecução foi culposa, teve como causa sua falta de diligência, deve ser condenado a ressarcir perdas e danos. Tal é compreensível pois a indenização é uma pena civil. Se o devedor tiver agido como bom pai de família, e ainda assim permanecer impedido de cumprir a obrigação, não seria justo que recebesse qualquer tipo de sanção.

O fortuito pode ser evento natural, externo ou dizer respeito à própria pessoa do devedor. É importante apenas que seja tal fato alheio à sua vontade. Fatos comuns e previsíveis podem, segundo o autor, impedir o adimplemento da obrigação e liberar o devedor, desde que a prestação seja impossibilitada sem culpa sua. Caso o devedor concorra para provocar o fato, ou não tome as cautelas necessárias para evitá-lo, o caso não será fortuito. Inclui-se no caso fortuito tudo o que transpõe os limites da

$\overline{110}$ GOMES, Orlando, "Obrigações", $17^{\mathrm{a}}$ edição, atualizada por Edvaldo Brito, editora Forense, 2008, p.181. 
diligência a que o devedor está adstrito. Dessa forma, Orlando Gomes filiase à teoria subjetiva e conceitua o caso fortuito como todo fato alheio à vontade do devedor, que o impossibilite de cumprir a obrigação ${ }^{111}$.

Além das teorias objetiva e subjetiva, há doutrinadores que defendem a teoria mista. Rui Stoco, ao citar Arnoldo Medeiros, ensina que, segundo ele, a noção de caso fortuito ou força maior decorre de dois elementos: um interno, de caráter objetivo, que seria a inevitabilidade do evento, e outro externo, de caráter subjetivo, que seria a ausência de culpa. Para Arnoldo Medeiros, não há acontecimentos que possam, a priori, ser definidos como caso fortuito, pois tudo dependeria das condições em que o evento aconteça ${ }^{112}$.

Arnoldo Wald demonstra entendimento semelhante ao definir caso fortuito e de força maior: "[N]o direito brasileiro, o caso fortuito e a força maior necessitam, para a sua prova, (...), da existência de dois elementos: um objetivo - a inevitabilidade do evento - e outro subjetivo - a ausência de culpa". O autor afirma, ainda, que há doutrinadores que confundem tais figuras jurídicas com a ausência de culpa, quando são critérios distintos para a exoneração de responsabilidade. A ausência de culpa é provada através da diligência do causador do dano, e o fortuito e a força maior

111 GOMES, Orlando, "Obrigações", $17^{\mathrm{a}}$ edição, atualizada por Edvaldo Brito, editora Forense, 2008, pp.179 a 182.

112 "Mostra Arnoldo Medeiros que a jurisprudência sempre se manteve fiel ao conceito clássico de caso fortuito, buscando caracterizá-lo pela imprevisibilidade ou inevitabilidade.

Segundo seu autorizado escólio, a noção de caso fortuito ou de força maior decorre de dois elementos: um interno, de caráter objetivo, ou seja, a inevitabilidade do evento, e outro, externo, ou "subjetivo", a ausência de culpa. Adota, pois, um conceito misto, no sentido de que "não há acontecimentos que possam, a priori, ser sempre considerados casos fortuitos; tudo depende das condições de fato em que se verifique o evento. O que é hoje caso fortuito, amanhã deixará de sêlo, em virtude do progresso da ciência ou da maior providência humana " (Caso Fortuito e Teoria da Imprevisão, 2. Ed. Rio de Janeiro: Forense, 1943, ns. 83 e s., p. 147).

Assim, um fato poderá, ou não, ser classificado como de força maior e isentará, ou não, de responsabilidade, conforme se possa caracterizar, ou não, por força do critério misto, quer dizer, pelo pressuposto da inevitabilidade e da ausência de culpa do agente". [STOCO, Rui, "Tratado de Responsabilidade Civil", $7^{a}$ edição, Editora Revista dos Tribunais, 2007, p. 181]. 
devem apresentar-se, também, como fato irresistível. Dessa forma, conclui o autor que a ausência de culpa é gênero, do qual o caso fortuito é espécie e, portanto, toda hipótese de fortuito ou força maior pressupõe a ausência de culpa, mas exigem, também, a existência de um fato impeditivo para que possam ser caracterizados ${ }^{113}$.

A adoção da teoria mista para a interpretação e aplicação do Artigo 393 do Código Civil parece ser a tendência da jurisprudência, apesar de o dispositivo em questão ter adotado a teoria objetiva. Nesse sentido, a decisão do Tribunal de Justiça do Distrito Federal e dos Territórios:

"[A] jurisprudência, outrossim, tem-se inclinado a admitir $o$ critério misto, a fim de aferir a isenção de responsabilização do devedor pela ocorrência de caso fortuito ou força maior, muito embora o legislador pátrio tenha optado pelo critério objetivo, como se observa da redação do art. 393 do novo Código Civil","114.

\subsubsection{Conceito e distinção de Agostinho Alvim}

Apesar das diversas distinções e conceituações de caso fortuito e força maior existentes na doutrina, a distinção feita por Agostinho Alvim é uma das poucas reconhecidas por seus efeitos práticos. A respeito da distinção, entende o autor que é: “(...) caso fortuito um impedimento

\footnotetext{
${ }^{113}$ WALD, Arnoldo, "Direito Civil - Direito das Obrigações e Teoria Geral dos Contratos", vol. 2, $18^{\mathrm{a}}$ edição, editora Saraiva, pp. 152 e 153.

114 Tribunal de Justiça do Distrito Federal e dos Territórios, apelação cível 20060111282125APC, Relatora Desembargadora Vera Andrighi, 21 de maio de 2008.

Nesse sentido, também:

Tribunal de Justiça do Distrito Federal e dos Territórios, apelação cível 1998.01.1.055581-6APC, Relator Desembargador Sérgio Bittencourt, DJ 04 de abril de 2001.

Superior Tribunal de Justiça, REsp 264.589/RJ, Relator Ministro Sálvio de Figueiredo Teixeira, quarta turma, 14 de novembro de 2000.
}

Superior Tribunal de Justiça, REsp 721.439/RJ, Relatora Ministra Eliana Calmon, segunda turma, 31 de agosto de 2007. 
relacionado com a pessoa do devedor ou com sua empresa, enquanto que a força maior é um acontecimento externo."115

Com a distinção, Agostinho Alvim pretende estabelecer tratamentos diversos para o agente, tendo em vista o fundamento de sua responsabilidade $^{116}$. No caso de responsabilidade fundada na culpa, responsabilidade subjetiva, o caso fortuito é suficiente para exonerar o autor do dever de indenizar. No entanto, nos casos de responsabilidade objetiva, fundada no risco, o caso fortuito não seria suficiente. Será necessário, então, que ocorra a força maior ou o caso fortuito externo ${ }^{117}$.

A força maior, capaz de exonerar o devedor quando se está diante da responsabilidade objetiva, é exemplificada por Agostinho Alvim como culpa da vítima, ordens de autoridades (fait $d u$ prince), fenômenos naturais (raio, terremoto), ou qualquer outra impossibilidade de cumprir com o avençado em função de fato derivado de força externa invencível, como guerras e revoluções. Mesmo nesses casos, o autor entende que é necessário analisar se o fato impeditivo não decorreu de qualquer culpa do autor do dano, ainda que indireta ou remota ${ }^{118}$.

\footnotetext{
${ }^{115}$ ALVIM, Agostinho Neves de Arruda, "Da Inexecução das Obrigações e suas Consequências", $4^{a}$ edição, Editora Saraiva, 1972, p. 330.

${ }^{116}$ SCAVONE JUNIOR, Luiz Antonio, "Causas e Cláusulas de Exclusão de Responsabilidade Civil"; in Revista de Direito Privado, n.8, outubro-dezembro de 2001, Editora Revista dos Tribunais, coordenação de Nelson Nery Junior e Rosa Maria de Andrade Nery

${ }^{117}$ Nas palavras de Agostinho Alvim:

"Tal distinção permite estabelecer uma diversidade de tratamentos para o devedor. Se esta fundar-se na culpa, bastará o fortuito para exonera-lo. Com a maioria de razão o absolverá a força maior. Se a sua responsabilidade fundar-se no risco, então o simples caso fortuito não exonerará. Será mister haja força maior ou, como alguns dizem, caso fortuito externo." [ALVIM, Agostinho Neves de Arruda, "Da Inexecução das Obrigações e suas Consequências", $4^{a}$ edição, Editora Saraiva, 1972, p. 330].

${ }^{118}$ ALVIM, Agostinho Neves de Arruda, "Da Inexecução das Obrigações e suas Consequências", $4^{a}$ edição, Editora Saraiva, 1972, p. 330
} 
Dessa forma, o autor afirma que a força maior é fato externo que não se liga à pessoa ou à empresa por nenhum laço de conexidade, enquanto o caso fortuito traduz a hipótese em que existe o nexo de causalidade entre o fato impeditivo e o devedor da obrigação ${ }^{119}$. Luiz Antonio Scavone Junior afirma que, com base em parte na doutrina de Agostinho Alvim, “(...) orienta-se a jurisprudência, que, da análise de cada caso concreto, com suas peculiaridades, acaba por diferenciar o fortuito interno do externo, determinando ou não o dever de indenizar" ${ }^{\prime 20}$. Por isso, resta claro que, dentre inúmeras diferenciações existentes na doutrina, aquela feita por Agostinho Alvim é de grande importância prática. Dessa forma, apesar de esta monografia tratar da exclusão de responsabilidade civil contratual subjetiva, foi dedicado um tópico específico à teoria apresentada.

\footnotetext{
${ }^{119}$ ALVIM, Agostinho Neves de Arruda, "Da Inexecução das Obrigações e suas Consequências", $4^{\mathrm{a}}$ edição, Editora Saraiva, 1972, p. 330.

${ }^{120}$ SCAVONE JUNIOR, Luiz Antonio, “Causas e Cláusulas de Exclusão de Responsabilidade Civil"; in Revista de Direito Privado, n.8, outubro-dezembro de 2001, Editora Revista dos Tribunais, coordenação de Nelson Nery Junior e Rosa Maria de Andrade Nery.
} 


\subsubsection{Requisitos da força maior ou do caso fortuito.}

Reza o parágrafo único do artigo 393 do Código Civil que: “O caso fortuito ou de força maior verifica-se no fato necessário, cujos efeitos não era possível evitar ou impedir". A partir desse dispositivo, a maioria dos doutrinadores afirma que são dois os requisitos do caso fortuito ou da força maior: a necessariedade e a inevitabilidade ${ }^{121}$.

$\mathrm{O}$ primeiro requisito caracteriza-se pelo fato necessário, para o qual não concorra o devedor de nenhum modo ${ }^{122}$. É o fato que resta fora da esfera de controle do devedor. Afirma Judith Martins Costa que "[A] "necessariedade" deve ser compreendida, pois, como a impossibilidade de o agente manter na sua própria esfera de controle o domínio do fato" $" 123$. Fato necessário é aquele que impede a realização da prestação e que é alheio ao controle do devedor.

$\mathrm{O}$ requisito da necessariedade do caso fortuito deve ser analisado de acordo com as circunstâncias de cada caso. De acordo com Agostinho

121 TEPEDINO, Gustavo, BARBOZA, Heloisa Helena, BODIN DE MORAES, Maria Celina, “Código Civil Interpretado conforme a Constituição da República”, vol. 1, editora Renovar, $2^{\mathrm{a}}$ edição, 2007, p. 710.

MARTINS-COSTA, Judith, "Comentários ao novo Código Civil", vol. V, tomo II: do inadimplemento das obrigações, Rio de Janeiro, Editora Forense, 2009, pp. 283 a 322.

SCAVONE JUNIOR, Luiz Antonio, "Causas e Cláusulas de Exclusão de Responsabilidade Civil"; in Revista de Direito Privado, n.8, outubro-dezembro de 2001, Editora Revista dos Tribunais, coordenação de Nelson Nery Junior e Rosa Maria de Andrade Nery.

GONÇALVES, Tiago Moraes, “O Caso Fortuito e a Força Maior Frente à Responsabilização Objetiva pelo Risco da Atividade na Sociedade Contemporânea", in Revista de Direito Privado, volume 47, jul-set./2011.

ALVIM, Agostinho Neves de Arruda, "Da Inexecução de suas Obrigações e suas Consequências", $4^{\mathrm{a}}$ edição, 1972, Saraiva, p. 326.

122 BARBOSA DA SILVA, Joaquim Marcelo, “As Cláusulas Excludentes e Limitadoras da Responsabilidade Contratual. Caso Fortuito e Força Maior"; Revista de Direito Privado, n. 6, abril - junho de 2001.

123 MARTINS-COSTA, Judith, "Comentários ao novo Código Civil”, vol. V, tomo II: do inadimplemento das obrigações, Rio de Janeiro, Editora Forense, 2009, p. 288. 
Alvim, "[A] necessariedade do fato há de ser estudada em função da impossibilidade do cumprimento da obrigação, e não abstratamente" ${ }^{\text {"124 }}$. A análise da necessariedade do fato deve ser feita à luz das circunstâncias do caso concreto, pois a esfera de controle do devedor é algo variável, que não deve ser definida abstratamente.

Judith Martins Costa entende que esse é um traço fundamental na avaliação do fortuito. $\mathrm{O}$ fato será considerado necessário, caracterizando o fortuito ou a força maior, de acordo com a situação concreta em que é verificado. Deve-se levar em consideração a possibilidade de conhecimento do fato pelo agente, usando a normal diligência, a sua impossibilidade de resistir ao evento ou de eliminá-lo, a extensão de seus deveres de garantia e o dever a ser efetivamente prestado ${ }^{125}$.

Agostinho Alvim exemplifica tal análise através do exemplo de uma pessoa, que durante certo período de tempo, guarda em casa grande soma de dinheiro que deve entregar a alguém. Então, ladrões, que têm conhecimento do fato, roubam o dinheiro em condições tais que fosse impossível impedir. Afirma o autor que, nessa hipótese, não se poderá admitir a escusa com base em caso fortuito. Ainda que a defesa contra os ladrões não fosse possível, o agente poderia evitar o acontecimento, depositando o dinheiro em um banco. Nesse caso, não terá havido a impossibilidade de afastar o evento que impediu o cumprimento da obrigação, já que o inadimplemento se deu por falta de cautela ${ }^{126}$.

\footnotetext{
124 ALVIM, Agostinho Neves de Arruda, "Da Inexecução de suas Obrigações e suas Consequências", $4^{\mathrm{a}}$ edição, 1972, Saraiva, p. 326.

${ }^{125}$ MARTINS-COSTA, Judith, "Comentários ao novo Código Civil", volume V, tomo II: do inadimplemento das obrigações, Rio de Janeiro, Editora Forense, 2009, p. 288.

126 ALVIM, Agostinho Neves de Arruda, "Da Inexecução de suas Obrigações e suas Consequências", $4^{\mathrm{a}}$ edição, 1972, Saraiva, p. 326.
} 
Ao elemento da necessariedade, agrega-se o da inevitabilidade. Apesar de outros sistemas jurídicos adotarem a imprevisibilidade ${ }^{127}$ do evento como requisito da força maior, o elemento apontado como relevante, no Direito Brasileiro, é o da inevitabilidade ${ }^{128}$. A inevitabilidade de que trata a lei não é propriamente a inevitabilidade do evento fortuito em si, mas de suas consequências para o adimplemento da obrigação. Segundo Luiz Antonio Scavone Junior, o caráter da inevitabilidade dos efeitos do evento é a característica em comum, que une os conceitos de fortuito e força maior ${ }^{129}$. Dessa forma, se o evento for imprevisível, mas tiver consequências evitáveis pelo devedor da obrigação, não estará configurada a impossibilidade por caso fortuito ou força maior.

Entende-se, assim, que a força maior é evento irresistível, que terá como consequência impedir que o devedor execute as prestações que

${ }^{127}$ O Código Civil Francês adotou a imprevisibilidade como característica da força maior. Sobre isso, afirma Alexandre Luiz Lucco: “(...) explica Mahmoud Reza Firoozmand, citando F. H. Lawson, que, para que ocorra força maior, é necessário que haja evento imprevisível pelas partes no momento de assinatura do contrato. Do contrário, se for previsível naquele momento, o devedor não poderá invocar força maior nem se escusar da obrigação." [LUCCO, Alexandre Luiz, "Caso Fortuito e Força Maior como Excludentes de Responsabilidade?", Revista Brasileira de Direito Civil Constitucional e Relações de Consumo, vol. 10, ano 3 - abril/junho 2011].

${ }^{128}$ MARTINS-COSTA, Judith, "Comentários ao novo Código Civil", volume V, tomo II: do inadimplemento das obrigações, Rio de Janeiro, Editora Forense, 2009, p. 290.

"Tem os autores concordado que a imprevisibilidade não se exige. Esta é tomada em consideração não como requisito autônomo, mas na medida em que o evento imprevisível mostrase, por isso mesmo, inevitável". [TEPEDINO, Gustavo, BARBOZA, Heloisa Helena, BODIN DE MORAES, Maria Celina, "Código Civil Interpretado conforme a Constituição da República", volume 1, editora Renovar, $2^{\mathrm{a}}$ edição, 2007, p. 710.]

"É preciso salientar que a imprevisibilidade não é requisito necessário da força maior e do caso fortuito, podendo um fato ser previsivel mas irresistível e ser, por esse motivo, considerado como caso fortuito ou força maior (v.g., uma inundação ou até a complete falta de chuvas, que levou ao racionamento de eletricidade)." [WALD, Arnoldo, "Direito Civil - Direito das Obrigações e Teoria Geral dos Contratos", vol. 2, $18^{\mathrm{a}}$ edição, editora Saraiva, p. 153].

Apesar disso, há julgados que adotam a imprevisibilidade como requisito para a configuração do fortuito, de acordo com o Artigo 393 do Código Civil Brasileiro, tais como as decisões do Tribunal de Justiça de Minas Gerais, 1.0024.09.710133-1/001, Relator Desembargador Tiago Pinto, 09 de setembro de 2012 e do Superior Tribuna de Justiça, AgRg no Recurso Especia n. 725.864/PR, Relatora Ministra Maria Isabel Gallotti, 21 de agosto de 2012.

${ }^{129}$ SCAVONE JUNIOR, Luiz Antonio, "Causas e Cláusulas de Exclusão de Responsabilidade Civil"; in Revista de Direito Privado, n.8, outubro-dezembro de 2001, Editora Revista dos Tribunais, coordenação de Nelson Nery Junior e Rosa Maria de Andrade Nery. 
prometera ao credor. De forma semelhante à análise da necessariedade do evento, é importante perceber que a inevitabilidade é relativa no tempo e no espaço. É preciso levar em consideração a pessoa e o evento de forma situada, em relação ao tempo e ao espaço, ao ambiente ou contexto. Ao se analisar o fortuito, a inevitabilidade relevante é aquela que ocorre para as pessoas do círculo em que vive o devedor, para as pessoas de sua profissão $^{130}$.

Outra questão relevante quanto à inevitabilidade do evento, é a análise do grau de dificuldade necessário para que o requisito esteja configurado. Afirma Judith Martins Costa que “(...) o acontecimento deve ser fundamentalmente inevitável (no sentido de "irresistivel”) assim não se caracterizando a mera dificuldade, ainda que grande". A autora dá o exemplo de um construtor que encontra um terreno difícil para instalar as fundações do prédio, exigindo esforços maiores do que os planejados, mas que não pode esquivar-se da obrigação avençada alegando força maior. Tal ocorre pois a mera dificuldade está na parcela de risco existente em todos contratos $^{131}$.

Com esse posicionamento concorda Agostinho Alvim, para quem a dificuldade de cumprir a obrigação não exonera o devedor. Segundo ele, "[A]inda que seja com sacrifício e aumento de ônus, terá ele que cumpri-la, e só se exonerará se lhe não for isto possível". No entanto, afirma o autor que há certas dificuldades que podem ser consideradas como impossibilidades, em função do grande aumento de ônus que o

\footnotetext{
130 MARTINS-COSTA, Judith, "Comentários ao novo Código Civil", vol. V, tomo II: do inadimplemento das obrigações, Rio de Janeiro, Editora Forense, 2009, p. 291.

131 MARTINS-COSTA, Judith, "Comentários ao novo Código Civil”, vol. V, tomo II: do inadimplemento das obrigações, Rio de Janeiro, Editora Forense, 2009, p. 291.
} 
cumprimento da obrigação acarretaria ao devedor. Nestes casos, o aumento da dificuldade, então, constituiria causa suficiente para exonerar o agente ${ }^{132}$.

Há autores que discordam da abordagem apresentada, pois entendem que a impossibilidade por caso fortuito estará suficientemente caracterizada pela ausência de culpa do devedor da obrigação, de forma que não elencam a inevitabilidade como requisito para a configuração do fortuito. Como já dito, Orlando Gomes afirma que a regra geral é de que o devedor deve indenizar os prejuízos decorrentes do inadimplemento sempre que resultem de culpa sua. No entanto, se o devedor agiu como bom pai de família e, ainda assim, continuar impossibilitado de cumprir com o contrato, não seria justo que sob ele incidisse uma indenização ${ }^{133}$. Assim, nota-se uma discordância entre os doutrinadores acerca do requisito da inevitabilidade. Portanto, apesar de a inevitabilidade ser um requisito legal do caso fortuito, elencado no parágrafo único do artigo 393, alguns entendem que a diligência esperada de um bom pai de família é suficiente na análise de sua caracterização, enquanto outros afirmam que a simples dificuldade não escusa o devedor, sendo para isso necessária a presença da impossibilidade de cumprir com o dever de $\operatorname{prestar}^{134}$.

\subsection{Efeitos da aplicação do caso fortuito e força maior.}

Via de regra, o devedor não responderá pelos prejuízos sofridos pelo credor em função da inexecução, quando esta é consequência de caso fortuito ou de força maior. A doutrina tradicional entendia que o fortuito era excludente da própria culpa e, por isso, da responsabilidade. No entanto, a

\footnotetext{
132 ALVIM, Agostinho Neves de Arruda, "Da Inexecução de suas Obrigações e suas Consequências", $4^{a}$ edição, 1972, Saraiva, p. 328.

${ }^{133}$ GOMES, Orlando, "Obrigações", $17^{\mathrm{a}}$ edição, atualizada por Edvaldo Brito, editora Forense, 2008, p. 180.

134 ALVIM, Agostinho Neves de Arruda, "Da Inexecução de suas Obrigações e suas Consequências", $4^{\mathrm{a}}$ edição, 1972, Saraiva, p. 328.
} 
doutrina mais moderna entende que é o nexo de causalidade que é rompido com a ocorrência do fortuito, já que o evento é causa estranha à conduta do agente. Portanto, afirma-se que as excludentes de responsabilidade civil atuam no nexo causal. É por esta razão que, mesmo quando não se cogita de culpa, o caso fortuito exonerará o obrigado ${ }^{135}$.

Entende-se que o Artigo 393 do Código Civil estabelece o princípio da exoneração do devedor pela impossibilidade de cumprir a obrigação sem culpa sua, uma vez que anuncia a sua irresponsabilidade pelos danos decorrentes de caso fortuito ou força maior ${ }^{136}$. Nesse sentido, afirma a decisão do Superior Tribunal de Justiça: “(...) se o caso fortuito ou de força maior for definitivo, impossibilitando absolutamente o cumprimento da obrigação, haverá a resolução do contrato" ${ }^{137}$.

No entanto, não é sempre que a ocorrência de caso fortuito ou força maior exonerará o devedor. Não haverá a exoneração de responsabilidade civil contratual quando (i) as partes convencionarem expressamente que o devedor responderá pelo cumprimento da relação obrigacional, ainda que haja a ocorrência de fortuito; (ii) o devedor estiver em mora, caso em que responderá não só pelos prejuízos decorrentes de seu atraso, mas também pela impossibilidade da prestação resultante de fortuito ocorrido durante a mora $^{138}$; e quando (iii) o devedor tiver de cumprir obrigação de dar coisa

\footnotetext{
135 TEPEDINO, Gustavo, BARBOZA, Heloisa Helena, BODIN DE MORAES, Maria Celina, "Código Civil Interpretado conforme a Constituição da República”, volume 1, editora Renovar, $2^{\mathrm{a}}$ edição, 2007, p. 711.

${ }^{136}$ Nesse sentido, afirma recente decisão do Superior Tribunal de Justiça que:

"O roubo mediante uso de arma de fogo é fato de terceiro equiparável à força maior, que deve excluir o dever de indenizar, mesmo no sistema de responsabilidade civil objetiva, por se tratar de fato inevitável e irresistível que gera uma impossibilidade absoluta de não ocorrência do dano". [Superior Tribunal de Justiça, Recurso Especial n. 976.564/SP, Relator Ministro Luis Felipe Salomão, 2012].

137 Superior Tribunal de Justiça, Recurso Especial n.1.054.992/MT, Relator Ministro Sidnei Beneti, 2008.

${ }^{138}$ Código Civil Brasileiro, artigo 399:
} 
incerta, pois antes da escolha não poderá alegar perda ou deterioração da coisa, ainda que decorrente de fortuito ${ }^{139}$. Além disso, se o evento fortuito ou decorrente de força maior não causar a impossibilidade total da prestação, o devedor estará eximido de cumprir apenas a parte atingida, de forma que não poderá invocar a força maior ou o fortuito para alcançar a liberação absoluta do dever de prestar ${ }^{140}$. Nesse sentido, novamente afirma a decisão do Superior Tribunal de Justiça: “A liberação dos efeitos da mora não implica, de forma alguma, a exoneração do cumprimento da obrigação contratual, mas tão-somente do cumprimento da obrigação de indenizar os prejuízos decorrentes do inadimplemento daquela obrigação contratual"141.

Caso a impossibilidade decorrente de fortuito seja temporária, como ocorre nos contratos de execução continuada, não haverá a resolução do contrato, mas apenas sua suspensão. Tratando-se de contratos bilaterais, havendo impossibilidade do cumprimento da obrigação por um dos contraentes em função de força maior, ele estará exonerado da sua obrigação de prestar e consequentemente o outro contraente também estará exonerado de sua própria obrigação, embora a contraprestação devida possa ser satisfeita. Com a extinção da obrigação de um, não é possível exigir a

"O devedor em mora responde pela impossibilidade da prestação, embora essa impossibilidade resulte de caso fortuito ou de força maior, se estes ocorrerem durante o atraso; salvo se provar isenção de culpa, ou que o dano sobreviria ainda quando a obrigação fosse oportunamente desempenhada."

Nesse sentido, decisão do Tribunal de Justiça de Minas Gerais, 1.0701.05.127424-2/001, Relator Desembargador Afrânio Vilela, 06 de agosto de 2008:

"A teor do art. 399 do Código Civil de 2002, o devedor que está em mora responde pela impossibilidade da prestação, mesmo que resulte de caso fortuito ou de força maior, se estes ocorrerem durante o atraso no inadimplemento".

${ }^{139}$ Código Civil Brasileiro, artigo 246:

"Antes da escolha, não poderá o devedor alegar perda ou deterioração da coisa, ainda que por força maior ou caso fortuito."

${ }^{140}$ DINIZ, Maria Helena, "Curso de Direito Civil Brasileiro", Segundo volume, Editora Saraiva, $17^{\mathrm{a}}$ edição, 2003, pp. 253 e 254.

141 Superior Tribunal de Justiça, Recurso Especial n.1.054.992/MT, Relator Ministro Sidnei Beneti, 2008. 
contraprestação do outro, pois a obrigação terá perdido sua causa, rompendo-se o vínculo de conexão entre as obrigações. Caso a outra parte já houver cumprido sua prestação, o contraente exonerado será obrigado a restituir o que recebeu ${ }^{142}$.

Diferentemente da CISG, no Código Civil a aplicação da cláusula de exoneração de responsabilidade civil em questão implicará na impossibilidade de exigir-se do devedor qualquer atitude diferente da devolução da contraprestação já efetuada, pois sua incidência gera a liberação do agente em relação à prestação impedida por fortuito, ocasionando a suspensão ou a resolução do contrato.

\subsection{Análise do caso hipotético apresentado à luz do Artigo 393 do Código Civil Brasileiro.}

Uma vez esclarecidos o conceito e os requisitos de caso fortuito e força maior no Direito Civil Brasileiro, passaremos agora à análise do caso hipotético apresentado à luz do Artigo 393 do Código Civil. Inicialmente, cabe ressaltar que em função da identidade de efeitos conferida pela lei civil ao caso fortuito e a força maior, trataremos os institutos como sinônimos.

O caso apresentado envolve a compra de aparato para conferências de alta tecnologia, a ser instalado no novo iate do comprador. $\mathrm{O}$ vendedor obrigou-se a finalizar a instalação de tal aparato em data certa, mas foi impedido de cumprir com a obrigação no tempo avençado em função de incêndio ocorrido na fábrica de seu fornecedor.

De forma diversa da CISG, o Código Civil não distingue os casos em que há a presença de um fornecedor ou subcontratado daqueles em que o devedor cumpre pessoalmente com suas obrigações. Por isso, é irrelevante

${ }^{142}$ DINIZ, Maria Helena, “Curso de Direito Civil Brasileiro”, vol. 3, Editora Saraiva, $18^{a}$ edição, 2003, pp. 156 e 157. 
para a análise da exclusão de responsabilidade civil, à luz do Artigo 393, que o acidente tenha ocorrido na fábrica do fornecedor do vendedor.

A análise da aplicação do Artigo 79 da CISG não envolve a aferição de culpa do devedor, vez que se restringe à adequação do inadimplente aos requisitos estabelecidos no parágrafo primeiro do dispositivo. Tal análise difere muito daquela estabelecida no Código Civil Brasileiro, para o qual a responsabilidade contratual é subjetiva, fundada na culpa do agente. Salvo exceções expressas em lei, entende-se que "na esfera contratual, apenas teria lugar a responsabilidade com culpa" ${ }^{" 143}$. Dessa forma, a análise da culpa do devedor é imprescindível para a caracterização da exclusão de responsabilidade civil contratual de acordo com o Artigo 393 do Código Civil Brasileiro.

Como já mencionado, de acordo com a teoria mista sobre a conceituação de caso fortuito, aquela adotada majoritariamente pela jurisprudência, a caracterização de tal evento depende de dois elementos: um de caráter subjetivo, que seria a ausência de culpa, e outro de caráter objetivo, que seria a inevitabilidade do evento. Quanto à ausência de culpa, devemos analisar a falta de diligência do devedor da obrigação. Caso a inexecução seja culposa, ocasionada por dolo do devedor, ou decorrente de sua negligência, imprudência ou imperícia, o elemento subjetivo do fortuito não estará caracterizado. No caso apresentado, a inexecução foi causada por incêndio na fábrica de um fornecedor do devedor. Claramente, o acontecimento não resultou de dolo do devedor, ou tão pouco de culpa sua. Dessa forma, entendemos que a ausência de culpa estaria caracterizada no caso hipotético apresentado.

\footnotetext{
${ }^{143}$ TEPEDINO, Gustavo, BARBOZA, Heloisa Helena, BODIN DE MORAES, Maria Celina, "Código Civil Interpretado conforme a Constituição da República", vol. 1, editora Renovar, $2^{a}$ edição, 2007, p. 705.
} 
No tocante ao caráter objetivo, a inevitabilidade a ser analisada não é propriamente a do fortuito em si, mas de suas consequências para o adimplemento da obrigação. A análise da inevitabilidade das consequências do fortuito deve ser feita à luz das circunstâncias do caso concreto.

No caso apresentado, o fornecedor do vendedor não entregou as unidades de processamento necessárias para a fabricação do aparato para conferências de alta tecnologia. Para evitar que o incêndio na fábrica do fornecedor ocasionasse o atraso na entrega do bem em questão, o vendedor poderia ter comprado outro sistema de conferências, ou outras unidades de processamento. Tendo em vista que a confecção de um aparato de alta tecnologia é feita a partir de peças menores, como as unidades de processamento, para utilizar unidades diferentes, o vendedor teria que refazer todo o seu sistema de conferências, o que geraria custos altíssimos. Da mesma forma, comprar um outro sistema de conferências às pressas para conseguir cumprir com o contrato através de um bem substituto também geraria prejuízos ao vendedor, já que não se trata aqui de um bem fungível, para o qual há vasto mercado.

No Direito brasileiro há divergência doutrinária no tocante ao grau de dificuldade a ser exigido do devedor na mitigação dos danos causados por evento fortuito. Há autores que afirmam que a conduta a ser exigida do devedor na superação das consequências do fortuito é aquela do bom pai de família, do homem médio. No entanto, mesmo os autores que exigem maior grau de sacrifício, entendem que a grande dificuldade pode ser considerada como impossibilidade em função do excessivo aumento de ônus para o devedor da obrigação. No caso apresentado, o vendedor só conseguiria impedir a ocorrência do fortuito caso suportasse em enorme prejuízo, vez que teria que reestruturar toda a sua linha de produção ou comprar outro sistema de conferências, inteiramente novo e às pressas. Dessa forma, 
acreditamos que a inevitabilidade das consequências do fortuito, de acordo com o Direito Brasileiro, estaria caracterizada.

Por último, deve ser analisado o requisito da necessariedade do evento, estabelecido no parágrafo único do Artigo 393. O fato necessário é aquele que resta fora da esfera de controle do devedor, para o qual ele não concorreu. Da mesma forma, esse requisito deve ser analisado à luz das circunstâncias de cada caso, pois a esfera de controle é algo variável. No caso apresentado, o evento resta fora da esfera de controle do devedor uma vez que não ocorreu em seu estabelecimento, mas de um terceiro, e que pressupomos que o mesmo adotou todas as medidas preventivas adequadas.

Percebe-se que, de acordo com o Artigo 393 do Código Civil Brasileiro, o devedor da obrigação provavelmente seria exonerado da obrigação de indenizar o credor, em oposição ao que acontece com a aplicação do Artigo 79 da Convenção. É certo que quando a inexecução é consequência de caso fortuito ou força maior, "o devedor não responderá pelos prejuízos sofridos pelo credor em virtude da inexecução" ${ }^{144}$.

\section{$* * *$}

144 TEPEDINO, Gustavo, BARBOZA, Heloisa Helena, BODIN DE MORAES, Maria Celina, "Código Civil Interpretado conforme a Constituição da República", vol. 1, editora Renovar, $2^{a}$ edição, 2007, p. 711. 


\section{CONCLUSÃO}

É sempre difícil fornecer respostas coerentes aos problemas que surgem quando circunstâncias inesperadas ocasionam o inadimplemento contratual. Os acontecimentos são os mais diversos - guerras, tempestades, incêndios, inundações, terremotos, greves, falência de um fornecedor, embargos governamentais, mudanças legislativas - são todos exemplos de eventos enfrentados pelos contratantes, com variáveis graus de dificuldade e previsibilidade. A questão é difícil, porém objetiva. O que se quer determinar é se a parte inadimplente será responsável pelo pagamento de indenização por perdas e danos quando da ocorrência de tais situações.

Ao longo desse trabalho, analisamos as disposições do Código Civil Brasileiro e da CISG, mais especificamente os Artigos 393 e 79, que pretendem resolver a questão.

Apesar de destinada a regular grande leque de relações comerciais, uma vez que aplicável a inúmeras trocas internacionais, a CISG, no tocante à exclusão de responsabilidade civil, é bastante rígida e objetiva. Talvez, porque destina-se a uma única modalidade de contratos: os contratos internacionais de compra e venda de mercadorias. Criada para regular apenas um tipo de relação jurídica, a Convenção, em seu Artigo 79, conseguiu criar regra bastante consistente. Há quatro requisitos, expressos no artigo, que devem ser satisfeitos para que o devedor inadimplente seja exonerado da obrigação de pagar perdas e danos. Apesar de o termo "impediment" utilizado pela Convenção ser aberto, não há muito espaço para criação doutrinária acerca dos requisitos estabelecidos.

No âmbito da exclusão de responsabilidade na CISG, o Artigo 79(2), é o dispositivo que gera maiores discussões em função de sua obscuridade, vez que não há certeza quanto a quem são as "third parties" nele referidas. 
Mas é exatamente por gerar incertezas que tal dispositivo raramente é aplicado. Como já aludido, o Artigo 7(1) da Convenção fala expressamente na necessidade de se promover a uniformidade em sua aplicação. Dessa forma, parece haver consenso na doutrina e na jurisprudência no sentido da não aplicação do Artigo 79(2), exatamente para que se evitem polêmicas e grandes divergências na interpretação e aplicação da CISG.

Talvez porque direcionado a mais de um tipo de relação jurídica, o Código Civil, ao contrário da CISG, criou regra aberta, que gera interpretações bastante diferentes. Em primeiro lugar, não há menção expressa no Artigo 393 à análise de culpa do devedor. Apesar disso, grande parte da doutrina e jurisprudência entende que a análise da culpa deve sempre existir, pois o devedor que age com culpa ou dolo não será exonerado da obrigação.

Da mesma forma, o Artigo 393 não estabelece claramente quais são os requisitos necessários para a configuração da exoneração de responsabilidade, e qual o grau de dificuldade a ser exigido do devedor da obrigação. Assim, apesar de a maioria dos doutrinadores entenderem que os requisitos são apenas aqueles claramente expressos no artigo, ou seja, a necessariedade do fato e efeitos impossíveis de serem evitados ou impedidos, não há consenso quanto ao grau de dificuldade a ser exigido. Alguns autores não enfrentam a questão, e aqueles que o fazem, tem interpretações bastante divergentes - há quem entenda que a diligência a ser exigida do devedor é aquela do bom pai de família, e outros afirmam que apenas a dificuldade que torna impossível o cumprimento da obrigação será suficiente para caracterizar a exoneração de responsabilidade através do Artigo 393.

A mesma divergência não aparece no estudo da Convenção que, além de ser objetiva e não dar espaço para a análise de culpa, é bastante 
rígida e estabelece elevado grau de dificuldade para que o devedor alcance a exoneração de responsabilidade.

Apesar das semelhanças e diferenças encontradas em pontos específicos de cada artigo, a principal divergência encontrada entre as legislações analisadas foi em suas interpretações. A internacional promove entendimentos semelhantes e suscita certa segurança de que a sua aplicação não gerará resultados opostos. É regra mais fechada, que não admite interpretações absolutamente divergentes e não gera excessivas dúvidas no intérprete.

Ao contrário, o Artigo 393 do Código Civil Brasileiro admite interpretações absolutamente divergentes. Existem tantos conceitos de eventos de caso fortuito e força maior, que a doutrina desistiu de conceituálos, vez possuem efeitos idênticos. Da mesma forma, não há consenso quanto aos requisitos necessários para a configuração de fortuito e do critério para estabelecê-lo. Por fim, tão pouco há concordância quanto ao grau de dificuldade a ser exigido do devedor frente a situação de força maior.

Conclui-se, então, que a regra brasileira gera insegurança jurídica. Não é possível prever como o Artigo 393 será aplicado pelos Tribunais Brasileiros. De fato, a tentativa exposta acima de aplicar o dispositivo ao caso concreto apresentado foi apenas uma sugestão, feita com a consciência de que se de fato julgado, o caso poderia gerar resultado diametralmente oposto àquele sugerido por esta monografia. Portanto, espera-se que com a adoção da CISG pelo Brasil e aplicação do Artigo 79 pelos Tribunais Brasileiros, maior segurança seja conferida também às transações comerciais nacionais. 


\section{BIBLIOGRAFIA}

ALMEIDA PRADO, Maurício; "Interpretação e aplicação da regra de "Exoneração" da Convenção de Viena (1980)". Esse estudo foi inicialmente publicado no livro "Arbitragem Internacional - UNCITRAL, CISG e Direito Brasileiro", Editora Quartier Latin, 2010.

ALVIM, Agostinho Neves de Arruda, "Da Inexecução de suas Obrigações e suas Consequências", Editora Saraiva, $4^{\mathrm{a}}$ edição, 1972.

BARBOSA DA SILVA, Joaquim Marcelo, "As Cláusulas Excludentes e Limitadoras da Responsabilidade Contratual. Caso Fortuito e Força Maior"; disponível em Revista de Direito Privado, n. 6, abril - junho de 2001.

BUTLER, Allison E., "A Practical Guide to the CISG: Negotiations Through Litigation" Aspen Publishers (2007 Supplements), disponível em http://cisgw3.law.pace.edu/cisg/biblio/butler6.html.

CARVALHO DOS SANTOS, J.M., "Código Civil Brasileiro Interpretado", vol. 14.

Caso Bullet-proof Vest, disponível em: http://cisgw3.law.pace.edu/cases/094505gr.html.

Caso Iron Molybdenum, disponível em http://cisgw3.law.pace.edu/cases/970228g1.html.

Caso Modular Wall Partitions, disponível em http://cisgw3.law.pace.edu/cases/031029s1.html. 
Caso

Vine

Wax,

disponível

em

http://cisgw3.law.pace.edu/cases/990324g1.html.

CHENGWEI, Liu, "Remedies for Non-performance: Perspectives from CISG, UNIDROIT Principles \& PECL", disponível em http://www.cisg.law.pace.edu/cisg/biblio/chengwei.html.

CISG-AC Opinion no 5, "The buyer's right to avoid the contract in case of non-conforming goods or documents" 7 de maio de 2005, Badenweiler (Germany). Rapporteur: Professor Dr. Ingeborg Schwenzer, LL.M., Professor of Private Law, University of Basel. Adotado pela CISG-AC na $9^{a}$ reunião feita na Filadélfia, com unanimidade, disponível em: http://www.cisg.law.pace.edu/cisg/CISG-AC-op5.html.

CISG-AC Opinion No. 7, "Exemption of Liability for Damages under Article 79 of the CISG", Rapporteur: Professor Alejandro M. Garro, Columbia University School of Law, New York, N.Y., USA. Adotado pela CISG-AC na $11^{a}$ reunião, em Wuhan, República Popular da China, em 12 de Outubro de 2007, disponível em http://www.cisg.law.pace.edu/cisg/CISG-AC-op7.html.

CNA, "Electronic Component and Hardware Manufacturing Industry", Risk Control, Industry Guide Series, 2008 disponível em: http://www.cna.com/vcm_content/CNA/internet/Static\%20File\%20for\%20 Download/Risk\%20Control/Industry\%20Guide\%20Series/ElectronicComp onenent\&HdweMfg.pdf.

DIAS, Aguiar, "Da Responsabilidade Civil", Editora Forense, vol. 1, 6 edição. 
DINIZ, Maria Helena, "Curso de Direito Civil Brasileiro", Editora Saraiva, vol. $2,17^{\mathrm{a}}$ edição, 2003.

EISELEN, Siegfried, "A Comparison of the Remedies for Breach of Contract under the CISG and South African Law", disponível em: http://www.cisg.law.pace.edu/cisg/biblio/eiselen2.html.

ENDERLEIN, Fritz e MASKOW, Dietrich, "International Sales Law, United Nations Convention on Contracts for the International Sale of Goods, Convention on the Limitation Period in the International Sale of Goods", Oceana Publications, 1992, disponível em http://www.cisg.law.pace.edu/cisg/biblio/enderlein.html\#art79.

ERIKSEN, Eivind (2004) "Terrorism and Force Majeure in International Contracts", Bond Law Review, Vol. 16, Iss. 2, Artigo 7, disponível em http://epublications.bond.edu.au/blr/vol16/iss2/7.

FERRARI, Franco, "The Interaction between the United Nations Conventions on Contracts for the International Sale of Goods and Domestic Remedies", disponível em http://www.cisg.law.pace.edu/cisg/biblio/ferrari16.html.

FLAMBOURAS, Dionysios P., "The Doctrines of Impossibility of Performance and clausula rebus sic stantibus in the 1980 Vienna Convention on Contracts for the International Sale of Goods and the Principles of European Contract Law: A Comparative Analysis" disponível em http://www.cisg.law.pace.edu/cisg/biblio/flambouras1.html.

FLAMBOURAS, Dyonisios, In: FELEMEGAS, John, “An International Approach to the Interpretation of the United Nations Convention on 
Contracts for the International Sale of Goods (1980) as Uniform Sales Law”, Cambridge University Press 2007.

FLECHTNER, Harry M., "Remedies Under the New International Sales Convention: The Perspective from Article 2 of the U.C.C.", disponível em http://www.cisg.law.pace.edu/cisg/biblio/flecht.html.

FM Global, "Safeguarding the Semiconductor Fabrication Facility", disponível em: http://www.cemag.us/article/safeguarding- semiconductorfabrication-facility.

GAMA JR., Lauro, "Hardship nos contratos internacionais: o papel revigorante dos Princípios do UNIDROIT na evolução da Convenção de Viena", Publicado na Revista Trimestral de Direito Civil, ano 11, jul/set 2010 .

GOMES, Orlando, “Obrigações”, Editora Forense, $17^{\mathrm{a}}$ edição, atualizada por Edvaldo Brito, 2008.

GONÇALVES, Tiago Moraes, "O Caso Fortuito e a Força Maior Frente à Responsabilização Objetiva pelo Risco da Atividade na Sociedade Contemporânea", in Revista de Direito Privado, vol. 47, jul-set./2011.

GUIDE TO CISG ARTICLE 79, Secretariat Commentary (closest counterpart to an Official Commentary), disponível em http://www.cisg.law.pace.edu/cisg/text/secomm/secomm-79.html.

HONNOLD, John, "Uniform Law for International Sales Under the 1980 United Nations Convention"; $3^{\text {a }}$ edição (1999), disponível em http://www.cisg.law.pace.edu/cisg/biblio/honnold.html. 
HUBER, Peter; MULLIS, Alastair, "The CISG: A New Textbook for Students and Practitioners", Sellier, European Law Publishers, 2007.

KATZ, Avery W., "Remedies for breach of contract under the CISG", disponível em http://www.columbia.edu/ ak472/papers/Katz,\%2025\%20Int\%20Rev\%20L $\% 20$ Econ\%20378\%20(2005)\%20(Remedies\%20for\%20Breach\%20of\%20

Contract\%20Under\%20the\%20CISG).pdf.

LAMAUD, Emmanuel, "Comparison Between the CENTRAL List and the Vienna Convention for the International Sale of Goods - Specific Topics (research paper 2006)", disponível em http://www.trans-lex.org/850000.

LEE, Wanki, "Exemptions of Contract Liability Under the 1980 United Nations Convention", disponível em http://www.cisg.law.pace.edu/cisg/biblio/lee.html.

LIU, Chengwei, "Force Majeure - Perspectives from the CISG, UNIDROIT Principles, PECL and Case Law" disponível em http://www.cisg.law.pace.edu/cisg/biblio/liu6.html\#fm119.

LOOKOFSKY, Joseph, “Article 79, Liability Exemptions for Failure to Perform; excerpt from The 1980 United Nations Convention on Contracts for the International Sale of Goods", disponível em http://www.cisg.law.pace.edu/cisg/text/secomm/secomm-79.html.

LUCCO, Alexandre Luiz, “Caso Fortuito e Força Maior como Excludentes de Responsabilidade?", in Revista Brasileira de Direito Civil Constitucional e Relações de Consumo, vol. 10, ano 3 - abril/junho 2011. 
MAGNUS, Ulrich, Hamburg, "The Remedy Of Avoidance Of Contract Under CISG-General Remarks And Special Cases" disponível em: http://www.uncitral.org/pdf/english/CISG25/Magnus.pdf.

MALUF, Carlos Alberto Dabus, "Caso Fortuito e Força Maior Excludentes de Culpabilidade", in Revista dos Tribunais, vol. 502, agosto de 1977.

MARTINS-COSTA, Judith, "Comentários ao novo Código Civil”, vol. V, tomo II: do inadimplemento das obrigações, Editora Forense, 2009.

NICHOLAS, Barry, "Impracticability and Impossibility in the U.N. Convention for the International Sale of Goods". disponível em http://www.cisg.law.pace.edu/cisg/biblio/nicholas1.html.

"Force Majeure and Frustration" 27 American Journal of Comparative Law (1979”), disponível em http://www.cisg.law.pace.edu/cisg/biblio/nicholas.html.

RIMKE, Joern, "Force majeure and hardship: application in international trade practice with specific regard to the CISG and the UNIDROIT Principles of International Commercial Contracts." disponível em: http://www.cisg.law.pace.edu/cisg/biblio/rimke.html.

RODRIGUES, Silvio, "Direito Civil", vol. 4, "Responsabilidade Civil", Editora Saraiva, 1989.

SALACUSE, Jeswald W., "Renegotiating International Business Transactions: The Continuing Strugle of Life Against Form", 35 Intllaw 1507, 1509, 2001. 
SCAVONE JUNIOR, Luiz Antonio, “Causas e Cláusulas de Exclusão de Responsabilidade Civil"; in Revista de Direito Privado, n.8, outubrodezembro de 2001.

SCHELECHTRIEM, Peter e SCHWENZER, Ingeborg, "Commentary on the UN Convention on the International Sale of Goods (CISG)", $3^{\mathrm{a}}$ edição, Oxford University Press, 2010.

SCHLECHTRIEM, Peter, "Commentary on Federal Supreme Court (Bundesgerichtshof), Civil Panel VII, in Review of the Convention on Contracts for the International Sale of Goods (CISG)", Kluwer Law International, 2000-2001.

SHERIN, Brian, "Comprehensive risk management for IC fabs", disponível em: http://www.electroiq.com/articles/sst/print/volum e-41/issue2/departments/news/comprehensive- risk-management-for-ic-fabs.html.

SHIN, Chang-Sop, "Declaration Of Price Reduction Under The Cisg Article 50 Price Reduction Remedy", disponível em: http://www.uncitral.org/pdf/english/CISG25/Shin.pdf.

Site

da UNCITRAL: http://www.uncitral.org/uncitral/en/uncitral_texts/sale_goods/1980CISG_st atus.html

SMYTHE, Donald J., "Bounded Rationality, The Doctrine of Impracticability, and the Governance of Relational Contracts", 13S. Cal. Interdisc. L. J. 227, 2004.

SPIVACK, Carla; "Of Shrinking Sweatsuits and Poison Vine Wax: A Comparison of Excuse for Nonperformance under the UCC and the CISG"; 
Oklahoma $\quad$ City $\quad$ University, em http://law.bepress.com/expresso/eps/1219.

STOCO, Rui, "Tratado de Responsabilidade Civil", 7ª edição, Editora Revista dos Tribunais, 2007.

STOLL, Hans, "Commentary on the U.N. Convention on the International Sale of Goods (CISG)", 2a edição, Peter Schlechtriem, Geoffrey Thomas trans., 1998.

Superior Tribuna de Justiça, AgRg no Recurso Especial n. 725.864/PR, Relatora Ministra Maria Isabel Gallotti, 21 de agosto de 2012.

Superior Tribunal de Justiça, Recurso Especial n.1.054.992/MT, Relator Ministro Sidnei Beneti, 2008.

Superior Tribunal de Justiça, Recurso Especial n. 976.564/SP, Relator Ministro Luis Felipe Salomão, 2012

Superior Tribunal de Justiça, REsp 264.589/RJ, Relator Ministro Sálvio de Figueiredo Teixeira, quarta turma, 14 de novembro de 2000.

Superior Tribunal de Justiça, REsp 721.439/RJ, Relatora Ministra Eliana Calmon, segunda turma, 31 de agosto de 2007.

TALLON, Denis in "Commentary on the International Sales Law: The 1980 Vienna Sale Convention", Cesare Massimo Bianca \& Michael Joachim Bonell, eds., Milan (1987), disponível em: http://www.cisg.law.pace.edu/cisg/biblio/tallon-bb79.html. 
TEPEDINO, Gustavo, BARBOZA, Heloisa Helena, BODIN DE MORAES, Maria Celina, "Código Civil Interpretado conforme a Constituição da República”, vol. 1, Editora Renovar, 2ª edição, 2007.

Tradução da CISG, feita por Eduardo Grebler e Gisely Radael, disponível em http://www.cisg-brasil.net/doc/egrebler2.pdf

Tradução da CISG, feita por Iacyr de Aguilar Vieira, disponível em http://www.cisg-brasil.net/doc/iacyr1.html.

Tribunal de Justiça de Minas Gerais, 1.0024.09.710133-1/001, Relator Desembargador Tiago Pinto, 09 de setembro de 2012.

Tribunal de Justiça de Minas Gerais, 1.0701.05.127424-2/001, Relator Desembargador Afrânio Vilela, 06 de agosto de 2008.

Tribunal de Justiça do Distrito Federal e dos Territórios, apelação cível 20060111282125APC, Relatora Desembargadora Vera Andrighi, 21 de maio de 2008.

Tribunal de Justiça do Distrito Federal e dos Territórios, apelação cível 1998.01.1.055581-6APC, Relator Desembargador Sérgio Bittencourt, DJ 04 de abril de 2001.

TRIPODI, Leandro, "Interpretação da CISG: contexto, lex forismo, uniformidade e o intuito do legislador convencional’.

UNCITRAL Digest of Case Law on the United Nations Convention on Contracts for the International Sale of Goods, p.388, Edição de 2012, disponível em http://www.uncitral.org/pdf/english/clout/CISG-digest-2012e.pdf. 
WALD, Arnoldo, "Direito Civil - Direito das Obrigações e Teoria Geral dos Contratos", vol. 2, $18^{\mathrm{a}}$ edição, Editora Saraiva. 